\title{
THE QUEST FOR ENABLING METAPHORS FOR LAW AND LAWYERING IN THE INFORMATION AGE
}

\author{
Pamela Samuelson*
}

Shamans, Software, and SpleEns: LAW and THE CONSTRUCTION OF THE INFORMATION SOCIETY. By James Boyle. Cambridge: Harvard University Press. 1996. Pp. xvi, 270. \$35.

Law In a Digital World. By $M$. Ethan Katsh. New York: Oxford University Press. 1995. Pp. viii, 294. \$35.

\section{INTRODUCTION}

It has become a truism, if not a cliché, that developments in information technologies are causing a fundamental transformation in society, taking us out of the industrial era and into an information age. ${ }^{1}$ The last few years have witnessed the appearance of an ample literature exploring this theme. ${ }^{2}$ Some may think that too much has already been written on this subject. Yet more books on this theme keeps rolling off the printing presses, including those by James Boyle 3 and M. Ethan Katsh ${ }^{4}$ that are the subject of this review. The continuing popularity of printed books on this subject seems rather ironic, for books are artifacts of a supposedly declining era.

* Professor of Law, University of Pittsburgh. B.A. 1971, M.A. 1972, University of Hawaii; J.D. 1976, Yale. - Ed. The author thanks Tom Bruce, Bob Glushko, and Peter Jaszi for their comments on an earlier draft of this review.

1. See, e.g., Bryan Appleyard, Economic Prophet of the Information Age, THE INDEPENDENT (London), Dec. 11, 1995, at 13.

2. See, e.g., Kevin Kelly, Out Of Control (1994); Nicholas Negroponte, Being Digrtal (1995); Ithiel de Sola Pool, Technologies of Freedom (1983); Shoshana Zuboff, IN the Age of the SMart Machine (1988).

3. Professor of Law, American University, Washington College of Law. Boyle's book elaborates on themes first developed in James Boyle, $A$ Theory of Law and Information: Copyright, Spleens, Blackmail, and Insider Trading, 80 CAL. L. REv. 1413 (1992).

4. Professor of Legal Studies, University of Massachusetts, Amherst. Katsh has published parts of his book as law review articles. See M. Ethan Katsh, Rights, Camera, Action: Cyberspatial Settings and the First Amendment, 104 YALE L.J. 1681 (1995); Ethan Katsh, Digital Lawyers: Orienting the Legal Profession to Cyberspace, 55 U. PrrT. L. Rev. 1141 (1994). 
Katsh and Boyle concern themselves with the impact of information technologies on law and the legal profession. ${ }^{5}$ Despite some overlap in the topical coverage in these two works - both, for example, give some attention to developments in copyright and privacy law - the books hardly could be more different. Boyle pays relatively little attention to the digital medium or to digital technologies. ${ }^{6}$ His focus is on the contradictory assumptions underlying justifications for decisions about the commodification of information. He points out that information is sometimes regarded as likely to be underproduced unless the law confers property rights on its producers; other times, information is regarded as something that must be freely available for the economy and democracy to operate in an optimal manner (Boyle, Chapter Four). Boyle explores how these contradictory conceptions about information play themselves out in particular legal decisions. He questions whether legal authorities and commentators have provided principled bases for invoking "property rights" or "public domain" rationales in those cases. Katsh, on the other hand, regards digital technologies as the driving force behind major transformations in law and the legal profession. Information as such is of only incidental interest to him. Katsh primarily hopes to help lawyers understand and adapt to coming changes so that they can avoid the obsolescence likely to overtake lawyers who resist these changes.

The books are also starkly different in tone. Boyle raises alarm about the course our society will likely chart in the absence of a social theory well-suited to promoting democratic values, justice, and efficiency in the information age. Katsh is more sanguine about the trajectory of the law in the information age, which causes Boyle to characterize him as a vague optimist. ${ }^{7}$ While Katsh does appear generally optimistic about the changes underway, just under the surface of his text lies a warning that lawyers must either change the way they practice law or risk being put out of business. Ultimately, however, Boyle explores the potential dark side of the information age in much greater depth than does Katsh. ${ }^{8}$

5. Two other recently published books that explore some information age legal issues are Paul Goldstein, Copyright's Highway (1994) and ANNe Wells Branscomb, Who OWNS INFORMATION? (1994).

6. Boyle explains that such a focus would require him to ignore the information policy issues arising from exploitation of genetic information. Boyle, p. 4.

7. Boyle, p. 202 n.7 (citing M. Ethan Katsh, The Electronic Media and the TransFORMATION OF LAW (1989)).

8. Boyle and Katsh do not stand alone in investigating these issues. For those who follow the literature about information as property or about the consequences of being digital, both books have much to offer not only for the sustained inquiry and insights they provide but also for the broad range of disciplines from which they draw ideas. Furthermore, those seeking initiation into the literature and controversial issues in each subject area will find these books helpful. Although the primary audience for both books is likely to be lawyers and law students, nonlawyers concerned with information policy and the impact of digital technologies 
Despite differences between the two books, they have at least one pervasive theme in common. Both authors are deeply concerned about the disabling consequences likely to attend hanging on to metaphors of the waning era. Both are in search of enabling metaphors suitable to the new era. Each has, of course, a different metaphor to offer as bête noire.

For Boyle, the disabling metaphor that should be discarded is the romantic concept of the creative author. This concept is asserted often to justify a broad grant of property rights in works of authorship. Boyle asserts:

[W] are driven to confer property rights in information on those who come closest to the image of the romantic author, those whose contributions to information production are most easily seen as original and transformative. I argue that this is a bad thing for reasons of both efficiency and justice; it leads us to have too many intellectual property rights, to confer them on the wrong people and dramatically to undervalue the interests of both sources of and audiences for the information we commodify. [Boyle, pp. $\mathrm{x}$-xi]

He hopes to elevate concerns for efficiency, justice, democratic values, and privacy to an equal status with concerns about creator interests so that judges and legislators who formulate legal rules about rights in information will do so in a more balanced manner.

Katsh seeks to overcome the disabling metaphor of print. $\mathrm{He}$ shows how much current legal doctrine and lawyering rely on printed material (Katsh, p. 8). He explains how and why digital technologies will fundamentally change the framework in which lawyers think about the law, substantive legal doctrine, and the manner in which lawyers will practice their profession (Katsh, $\mathrm{p}$. 16).

This review will assess the success of each author's effort to enable readers to overcome disabling metaphors of the past and to aid in the emergence of new metaphors that will better serve the information society of the future.

will find both books rich in information. Boyle is particularly adroit in demonstrating how complex social problems emerge as legal issues. The law, he says, is:

a complex interpretive activity, a practice of encoding and decoding social meaning that merges imperceptibly with rhetoric, ideology, "common sense," economic argument (of both a highly theoretical and a seat-of-the-pants kind), with social stereotype, narrative cliché and political theory of every level from high abstraction to civics class chant.

Boyle, p. 14. Court opinions explaining whether someone should be liable for a particular act or omission illustrate this complex interpretive activity. The underlying issues often interest nonlawyers as well as lawyers. Katsh's book holds a broader appeal because Katsh writes more as an anthropologist of the legal profession than as a practitioner or legal academic. Indeed, nonlawyers may find it easier than lawyers to read Katsh's diffuse and discursive writing, while lawyers probably have greater need to think about the issues he discusses. 


\section{Moving Beyond the Author Metaphor}

\section{A. Of Shamans and Spleens}

Boyle's book is less about shamans and spleens than its title might suggest. In fact, Boyle does not explain what shamans have to do with his thesis until Chapter Eleven. Spleens appear in Chapter Nine, but even then spleens are less the issue than the DNA borne in one man's spleen (Boyle, pp. 97-107). Boyle intends for his title to pique the curiosity of prospective readers about what shamans, software, and spleens could possibly have in common. Few are they who would find Law and the Construction of the Information Society as compelling a title as Shamans, Software, and Spleens. But Boyle does not use his title merely to grab the reader's attention. He also uses it to signal that his work will not be yet another dreary academic dissertation. Boyle delivers on the promise of his title: His book proves an enjoyable read; and he also explores the connection among shamans, software, and spleens.

So what do shamans have to do with the construction of the information society? To answer this question, one must understand a few basic principles of the intellectual property laws of Western industrialized nations. These laws typically grant exclusive rights to individual creators who develop certain kinds of intellectual products. Authors of original writings are eligible for copyright protection, and inventors of new machines or technological processes may qualify for patent protection. 9 Boyle regards these laws as embodiments of romantic concepts about individual creators. The romance lies in the idea of individual genius authors and inventors who are said to deserve property rights in the creative products that spring from their minds without regard to what has come before (pp. 16, 52-54).

Boyle argues that romantic entitlement theory yields laws that ignore creations that do not conform to the romantic creator model. For example, creations emanating from collective effort, such as the knowledge of shamans, are ineligible for protection under such laws because there is no one individual author-inventor to designate as the rightsholder. Armed with romantic entitlement notions, Westerners traveling to the outback of Australia or other exotic climes may regard as freely appropriable aboriginal designs, folklore, or shamanic knowledge that they find attractive or useful. After all, these creations do not derive from a particular author or inventor whose rights the Western appropriator would be violating. Consequently, Western explorers perceive the designs, folklore, and sha-

9. See 17 U.S.C. $\$ 102($ a) (1994) (making a copyright available to authors of original works); 35 U.S.C. $\$ 101$ (1994) (entitling an inventor to patent new and nonobvious technologies). 
manic knowhow of undeveloped or underdeveloped nations as raw material just waiting for Western creative discovery and exploitation. By mixing their labor with the appropriated subject matter and thereby refining it, Westerners could become romantic authorinventors entitled to intellectual property rights under their own culture's laws. ${ }^{10}$

Boyle makes both justice and efficiency arguments against the unfettered appropriation of shamanic and other collective creations from undeveloped nations. Boyle argues that justice requires Westerners to accept the rights of non-Western cultures to control the commercial exploitation of their collective creations (pp. 125-28). He urges Westerners to abandon - or at least moderate - the ideology that has blinded them from appreciating the valuable sources from which they draw products or understanding the justice claims of non-Western cultures.11 Predictably, Boyle approves of the efforts undertaken by some countries to protect their collective creations against Western exploitation.12 He also favors international recognition of intellectual property rights in collective works. ${ }^{13}$

Boyle's efficiency argument focuses on the potential shortsightedness of failing to compensate indigenous cultures for their knowhow or other collectively generated creative artifacts. Compensation may prevent destruction of resources necessary for the development of new products. Boyle considers the plight of Madagascar, "the unique home of perhaps 5 per cent of the world's

10. Boyle cites the example of a Western drug company that developed a cure for Hodgkin's disease from vinca alkaloids in the rosy periwinkle of Madagascar. The vinca alkaloids long had been used in Madagascar to treat diabetes. These therapeutic qualities led the company to investigate the plant, which led to the development of a drug that cures Hodgkin's disease and earns its manufacturer $\$ 100$ million per year. Madagascar shared in none of these profits. See pp. 127-29.

11. Boyle writes that:

At the moment, [the author concept] is a gate that tends disproportionately to favor the developed countries' contributions to world science and culture. Curare, batik, myths, and the dance "lambada" flow out of developing countries, unprotected by intellectual property rights, while Prozac, Levis, Grisham, and the movie Lambadal flow in-protected by a suite of intellectual property laws, which in turm are backed by the threat of trade sanctions.

P. 125.

12. See Boyle, p. 127 (citing Darrell Posey \& Graham Dutfield, Beyond INTEllectual PRoperty Rights: TOWARds TRaditional Resource Rights For INDigenous AND LoCAL COMMUNrrtes (1995)) (providing "indigenous communities with the first accessible summary of the existing intellectual property, human rights, indigenous rights, biodiversity, and environmental rules that bear on the issue").

13. See Boyle, app. B (The Bellagio Declaration) at 192 (indicating Boyle's participation in the authorship of this Declaration). This Declaration resulted from discussions conducted at the weeklong conference entitled Cultural Agency-Cultural Authority: The Politics and Poetics of Intellectual Property in the Post-Colonial Period. This conference was held at the Rockefeller Study Center at Bellagio, Italy, and was organized by Peter Jaszi and Martha Woodmansee. See Boyle, app. B at 192. 
species[:] It is the biological equivalent of an Arab oil sheikdom. Yet, without an income from its huge biological wealth, it has chopped down most of its forests to feed its people."14 Boyle responds with a quip and a more general observation:

Now there's a public goods problem. Precisely because they can find no place in a legal regime constructed around a vision of individual, transformative, original genius, the indigenous peoples are driven to deforestation or slash and burn farming. Who knows what other unique and potentially valuable plants disappear with the forest, what generations of pharmacological experience disappear as the indigenous culture is destroyed? [pp. 128-29]

Boyle urges the West to realize that compensating indigenous cultures for appropriations of their biological resources will serve the long-term interest of the West in the continued availability of those resources. Boyle leaves to others the job of addressing the complex questions that arise once one accepts the general concept that nonWestern cultures have a right to compensation for collective creations. ${ }^{15}$ Boyle's contribution is to call attention to some underlying assumptions of Western intellectual property law and to raise questions about the justice and efficiency of applying Western concepts to shamanic knowledge and other indigenous creations.

Spleens are of interest to Boyle because they raise questions about rights to control and benefit from the exploitation of genetic information. ${ }^{16}$ After doctors at the University of California surgically removed John Moore's spleen during his treatment for leukemia, medical researchers discovered that Moore's cells produced an unusually high quantity of lymphokines. Using genetic-engineering techniques, the researchers cloned Moore's genetic material. They then patented this cell line and licensed the patent to a drug company. The estimated commercial value of the patented cell line was three billion dollars. When Moore eventually learned of the commercialization of his cell line, he sued the Regents of the University of California for, among other things, wrongful conversion of his

14. P. 128 (quoting Fred Pearce, Science and Technology: Bargaining for the Life of the Forest - Poor Nations Want Drug and Food Companies to Pay for the Plants They Plunder, THE INDEPENDENT (London), Mar. 17, 1991, at 37 (internal quotation marks omitted)). See supra note 10 for an example of Western appropriation of a Madagascar plant without recompense to the indigenous people.

15. Boyle does not, for example, address questions such as whether the people of Madagascar should receive compensation whenever a Western company appropriates a plant or plant DNA from that country, whether it should be necessary for the plant to have been known to shamans of that country to claim a right of compensation, or whether mere knowledge by ordinary farmers, for example, of therapeutic qualities would suffice to trigger a right to compensation. Nor does he confront the even more difficult question of who would represent the collectivity for the purposes of receiving the compensation.

16. See pp. 97-118. 
property. ${ }^{17}$ Moore thought that he should share in the largesse deriving from the special characteristics of his DNA.

Boyle makes colorful use of the analytic morass in the appellate court opinions in the Moore case. The lower court, having made Moore's doctors "sound like high-tech vampires, sampling Moore's blood and bodily fluids for their own, hidden, purposes," decided that Moore had property rights in his genetic code (p. 99). In reaching the opposite conclusion, the California Supreme Court focused on the impact such a ruling would have on medical research. Boyle highlights the seemingly contradictory rhetorics of public domain and of property rights in the court's opinion:

Property rights given to those whose bodies can be mined for valuable genetic information will hamstring research because property is inimical to the free exchange of information. Yet property rights must be given to those who do the mining, because property is an essential incentive to research. How can the court tell when property rights will have the effect of stopping the flow of information and when they will be necessary to start that flow? [p. 101]

Boyle also sees traces of romantic entitlement theory in the supreme court's opinion. It discounted Moore's claim to property rights in his genetic material because his genetic information contained nothing particularly original. ${ }^{18}$ It approved of the grant of property rights to the medical researchers because they used ingenuity in converting the "naturally occurring raw material" of Moore's genetic code into a commercially valuable product. ${ }^{19}$

Although Boyle hints at some sympathy with Moore's claim, he ultimately rejects the privacy-personal autonomy basis for that sympathy:

[T] he market has taken from [Moore] the most "private" information of all, information about his own genetic structure. Yet our intuitive notions of privacy are constructed around the notion of preventing disclosure of intimate, embarrassing, or simply "personal" socially constructed facts about ourselves to others like ourselves. I could stare at my own genetic code all day and not even know it was mine. [p. 105]

Boyle goes on to observe that "[t]he difficulty with Moore's case is, first, that no one would think worse of him for having a genetic make-up that could be mined for a socially valuable drug and, second, that specialized knowledge would be necessary to make the connection between the 'facts revealed' and the 'inner life" ( $p$. 105). In the end, Boyle offers neither justice nor efficiency arguments in support of Moore's claim.

17. Moore v. Regents of the University of California, 249 Cal. Rptr. 494 (Ct. App. 1988), modified., 793 P.2d 479 (Cal. 1990), cert. denied, 499 U.S. 936 (1991).

18. See 793 P.2d at 490.

19. 793 P.2d at $492-93$. 
Although Boyle's criticism of the California Supreme Court's decision is witheringly good, he does not address the court's strongest argument. Upholding Moore's property claim would not just stop medical researchers from making unauthorized commercializations of patient cell lines; it would also render any unauthorized use of a patient's genetic material for research purposes a conversion of personal property. ${ }^{20}$ This would have a chilling effect on medical research. Boyle does not dispute this conclusion.

The California Supreme Court, as Boyle acknowledges, did not leave Moore completely without a remedy (p. 107). It upheld his claim that university researchers breached their fiduciary duty in failing to obtain his informed consent before doing research with his genetic material for potentially commercial purposes. The court decided that if public support existed for a right to compensation under these circumstances, the legislature could provide it. ${ }^{21}$ In the absence of such legislation, the court reached a reasonable result, even if it bumbled en route to its conclusion.

\section{B. Of Insider Trading and Blackmail}

For Boyle, insider trading and blackmail laws that forbid certain kinds of lucrative information exchanges are the flip side of the shaman and spleen problem. ${ }^{22}$ Boyle wonders why we permit the commodification of shamanic lore and genetic information when, we prohibit commodification of information for insider trading or blackmail purposes. Romantic entitlement theory would suggest that both insider trading and blackmail - at least that which pertains to lawfully obtained information - ought to be legal. The fact that both are illegal suggests that something other than romantic entitlement theory underlies these two bodies of law.

Boyle finds some choice examples of the rhetoric of romantic entitlement in the ample literature on insider trading. ${ }^{23}$ These examples conjure up the image of the creative entrepreneur, a person who, out of his sole genius, originates a new business and deserves to enjoy the fruits of his labors, including the fruits that derive from knowledge about his own business.

The literature on blackmail does not depict blackmailers in romantic terms. Not even Boyle goes to the trouble of conjuring up a romantic image of a blackmailer, but this is not hard to do. After all, it may require a considerable amount of time, money, and en-

20. Conversion is a strict liability rule; even inadvertent use of a patient's genetic material would be illegal. See 793 P.2d at 493-94.

21. See 793 P.2d at 496.

22. See chapter 7 (blackmail), chapter 8 (insider trading).

23. Pp. 92-95 (citing Henry ManNe, Insider Trading and the Stock Market (1996)). 
ergy, and no small amount of insight, to learn an embarrassing fact about a person. Developing a successful strategy for inducing the person to pay the blackmail also calls for creativity. Of course, a creative blackmailer sometimes may learn the embarrassing fact through pure serendipity, but if patent law does not disqualify a serendipitous inventor from entitlement to a patent, ${ }^{24}$ neither should the law regulating commercial exchanges about personal information.

The blackmail literature principally addresses economic explanations for the illegality of blackmail.25 Blackmail seems a clear instance in which commodification of information naturally would take place in the absence of legal rules forbidding it. Boyle provides a synopsis and critique of the various explanations for the illegality of blackmail, including those put forward by Richard Posner and Richard Epstein (pp. 62-72).

Boyle regards the promotion of privacy and personal autonomy values as the principal rationale for blackmail law (p. 77). He explains insider trading laws as laws that promote democratic values by ensuring relatively equal access to commercially valuable information affecting stock prices (p. 83). His thesis seems to be that blackmail and insider trading laws deserve careful study because they subsume romantic entitlement theory to other social values. Boyle, however, does not explain how democratic, privacy, or personal autonomy values can be used to moderate or subsume romantic entitlement theory in policymaking about intellectual property. Boyle leaves this job to his readers.

\section{Poetry v. Engineering Metaphors for Software}

Software sits between shamans and spleens in the title of Boyle's book, yet Boyle discusses software only briefly. He merely points to the substantial disagreement in the software industry about whether patent protection should be available for software innovation (p. 133), and calls attention to a group organized by a software genius that believes that patent protection for software impedes freedom of expression in programming. ${ }^{26}$ Perhaps the sheer volume of literature about intellectual property protection for software deterred Boyle from exploring software issues in more detail. ${ }^{27}$

24. See 35 U.S.C. \$ 103 (1994).

25. See, e.g., Ronald H. Coase, Blackmail, McCorkle Lecture delivered at the University of Virginia School of Law (Nov. 10, 1987), in 74 VA. L. REV. 655 (1988).

26. See pp. 132-33. Richard Stallman, who organized the League for Programming Freedom, received the MacArthur Fellowship known as the "genius" award. See, e.g., Nathan Cobb, Power to the Programmer, Boston Globe, Oct. 21, 1990 (Magazine), at 16.

27. See, e.g., Donald S. Chisum, The Patentability of Algorithms, 47 U. PrTt. L. REv. 959 (1986); Kenneth W. Dam, Some Economic Considerations in the Intellectual Property Protec- 
Boyle's limited foray into the software protection literature is unfortunate for two reasons. First, this literature provides some outstanding examples of the rhetoric of romantic entitlement. ${ }^{28}$ Second, recent software copyright cases demonstrate that judges sometimes do reject romantic entitlement arguments in applying copyright law to software. ${ }^{29}$

The best illustration of romantic entitlement rhetoric as applied to computer software is a law review article cleverly entitled Silicon Epics and Binary Bards. This article about the application of copyright law to computer programs was written by a group of IBM litigation attorneys. ${ }^{30}$ Computer programs are, of course, the "silicon epics" to which the title refers, and "binary bards" the programmers who write them. The article begins with a prefatory quote from an eminent computer scientist, Dr. Frederick Brooks. Brooks compares a programmer to a poet in that he "'works only slightly removed from pure thought-stuff. He builds his castles in the air, from air, creating by exertion of the imagination. Few media of creation are so flexible, so easy to polish and rework, so readily capable of realizing grand conceptual structures.' "31 Programming is fun, Brooks says, " "because it gratifies creative longings built deep within us and delights sensibilities we have in common with all men." "32 Silicon Epics derides as ignorant and mistaken the view that programs are a technology and that programmers are software engineers. 33

The authors of Silicon Epics are straightforward about why they characterize programmers as poets. The principal thesis of the arti-

tion of Software, 24 J. Legal Stud. 321 (1995); Dennis S. Karjala, Copyright, Computer Software, and the New Protectionism, 28 JuRIMETRIcs J. 33 (1987); Peter S. Menell, An Analysis of the Scope of Copyright Protection for Application Programs, 41 STAN. L. REv. 1045 (1989); Arthur R. Miller, Copyright Protection for Computer Programs, Databases, and Computer-Generated Works: Is Anything New Since CONTU?, 106 HaRv. L. Rev. 977 (1993); J.H. Reichman, Computer Programs as Applied Scientific Know-How: Implications of Copyright Protection for Commercialized University Research, 42 VAND. L. REv. 639 (1989); Pamela Samuelson et al., A Manifesto Concerning the Legal Protection of Computer Programs, 94 Colum. L. Rev. 2308 (1994).

28. See, e.g., Anthony L. Clapes et al., Silicon Epics and Binary Bards: Determining the Proper Scope of Copyright Protection for Computer Programs, 34 UCLA L. REv. 1493 (1987).

29. See, e.g., Computer Assocs. Intl., Inc. v. Altai Inc., 982 F.2d 693 (2d Cir. 1992).

30. See Clapes et al., supra note 28.

31. Id. at 1497 (quoting Frederick P. Brooks, JR., The MYthiCal MaN-MontH: EsSAYS ON SOFTWARE ENGINEERING 7 (1975)).

32. Clapes et al., supra note 28, at 1497 (quoting Brooks, supra note 31, at 7).

33. Clapes et al., supra note 28 , at 1501 n.19. Yet Brooks, the very source of Clapes's programmers-as-poets metaphor, regards programming as an engineering activity. In fact, Brooks subtitled his book "Essays On Software Engineering." See also Frederick P. Brooks, Jr., No Silver Bullet: Essence and Accidents of Software Engineering, CoMPUTER, Apr. 1987, at 10. For a discussion of the appropriateness of the engineering metaphor for software development, see Samuelson et al., supra note 27, at 2326-32, 2357-58, n.194. 
cle is that the "arcane epic poetry" 34 of computer programs so resembles traditional works of literature that programs should receive the same broad protection accorded to novels, plays, and poetry. Computer programs are "literary works" under the copyright statute..$^{35}$ If copyright law protects the detailed structure of a novel or dramatic play, so too, they argue, should it protect the detailed structure of computer programs. ${ }^{36}$ Although courts have not found the programmer-as-poet metaphor compelling, the syllogistic logic of the literary work metaphor has had considerable effect upon the software copyright case law. ${ }^{37}$

Recent decisions have taken the rhetorical turn that the authors of Silicon Epics hoped to avert. Once courts accept the technically accurate characterization of computer programs as utilitarian works, the inexorable result is that programs will have a thinner scope of copyright protection than works of art or literature.38 When Judge Walker rejected Apple Computer's argument that the design of the Macintosh user interface was artistic and fanciful and embraced Microsoft's argument that the design was largely functional,39 Apple was well on its way to losing its lawsuit.40 Armed with the rhetoric of functionality and a statutory provision that excludes functional design elements from the scope of copyright, ${ }^{41}$ courts lately have resisted arguments for a broad scope of copyright protection for software. They have become aware of the potential availability of patent protection for functional aspects of software innovations, and of the danger that overly broad copyright protection for computer programs could thwart competition policy concerns underlying both patent and copyright law. 42 Thus, the courts have held romantic entitlement rhetoric in check and have formulated rules that achieve competitively sensible results.

However much praise these courts may deserve for averting the overprotection likely to flow from unquestioning acceptance of the programs-as-poetry rhetoric, this praise should be tempered by an understanding that there is some danger - one that goes unnoticed

34. Clapes et al., supra note 28 , at 1584.

35. See 17 U.S.C. $\S 101$ (1994) (definitions of "computer program" and "literary works").

36. Clapes et al., supra note 28 , at $1548-58$, 1568-71.

37. See, e.g., Computer Assocs. Intl., Inc. v. Altai, Inc., 982 F.2d 693 (2d Cir. 1992); WheIan Assocs., Inc. v. Jaslow Dental Lab., Inc., 797 F.2d 1222 (3d Cir. 1986).

38. See, e.g., Sega Enters. Ltd. v. Accolade, Inc., 977 F.2d 1510, 1524 (9th Cir. 1992).

39. See Apple Computer, Inc. v. Microsoft Corp., 799 F. Supp. 1006 (N.D. Cal. 1992).

40. See Apple Computer, Inc. v. Microsoft Corp., 821 F. Supp. 616 (N.D. Cal. 1993), modified., 35 F.3d 1435 (9th Cir. 1994), cert. denied, 115 S. Ct. 1176 (1994).

41. 17 U.S.C. $\$ 102$ (b) (1994); Sega, 977 F.2d at 1522 (functional requirements for achieving compatibility with another program not protected under $\$ 102(b))$. 1992).

42. See, e.g., Atari Games Corp. v. Nintendo of Am. Inc., 975 F.2d 832, 842 (Fed. Cir. 
by Boyle - of underprotection of program innovation by existing law. This danger arises from the rapid, inexpensive appropriability of valuable program innovations ${ }^{43}$ embedded in programs as well as other commercially valuable information products. ${ }^{44}$ As Professor Jerome Reichman explains:

[M]uch of today's most advanced technology enjoys a less favorable competitive position than that of conventional machinery because the unpatentable, intangible knowhow responsible for its commercial value becomes embodied in products that are distributed in the open market. A product of the new technologies, such as a computer program, an integrated circuit design, or even a biogenetically altered organism may thus bear its know-how on its face, a condition that renders it as vulnerable to rapid appropriation by second-comers as any published literary or artistic work. 45

Existing forms of legal protection do not suffice to protect against the rapid appropriation of innovations revealed on the face of information products: Trade secret law does not protect information borne on or near the face of products sold in the open market. Copyright law does not protect know-how or industrial designs. Patent law does not protect incremental innovations, such as those typically embodied in computer programs. ${ }^{46}$

New forms of legal protection may be needed to provide artificial lead time to developers of incremental innovation bearing know-how on its face so that developers of these products have an opportunity to recoup their investments and make sufficient profits to justify further investments in these works. ${ }^{47}$ Although Boyle calls for sui generis forms of legal protection for computer programs (Boyle, p. 172), it is difficult to predict how he would react to the idea of granting additional legal protections to programs that would diminish the public domain he cherishes.

\section{Copyright and Social Dialogue}

Copyright is the body of law that currently embraces romantic entitlement theory most heartily. This was not always so. English "copy-rights" initially vested in publishers by virtue of the publishers' investments in purchasing manuscripts and in printing books. ${ }^{48}$

43. See Samuelson et al., supra note 27 , at $2333-42$.

44. See, e.g., J.H. Reichman, Legal Hybrids Between the Patent and Copyright Paradigms, 94 Colum. L. Rev. 2432 (1994).

45. J.H. Reichman, Design Protection and the New Technologies: The United States Experience in a Transnational Perspective (pt. 2), 1991 INDus. PROP. 251, 269.

46. For an analysis of the existing laws' failure to protect much of the valuable innovation in computer programs, see Samuelson et al., supra note 27, at 2342-64.

47. See, e.g., Reichman, supra note 44, at 2544-56; Samuelson et al., supra note 27, at 2378-428. (1968).

48. See, e.g., L. Ray Patterson, Copyright In Historical Perspective 8, $42-77$ 
The first author-centered copyright law, the English Statute of Anne in 1710, offered a utilitarian rationale for granting authors exclusive rights to control the printing of their books: Without a statutory grant of exclusive rights, authors might decline to write or publish at all. ${ }^{49}$ Not until the late eighteenth century did the romantic theory of authorship arise, and not until the nineteenth century did it make its way into the law. ${ }^{50}$ Romantic theory posited that authors deserve broad property rights in the products of their original genius. ${ }^{51}$ While this notion took a firm hold in Continental Europe, the utilitarian approach to copyright policymaking has historically predominated in the United States. ${ }^{52}$ Lately, however, the rhetoric of romantic entitlement has become more pronounced in the United States, as American copyright industries have gained ascendancy in both domestic and international markets. Boyle gives numerous examples of this recent trend (pp. 135-39, 141-42).

Notwithstanding this development, there is reason to be optimistic about the ability of U.S. copyright law to weigh in policy considerations other than those embodied in romantic entitlement theory. The values of justice, democracy, free expression, and personal autonomy are all reflected in U.S. copyright decisions. ${ }^{53}$ Other U.S. copyright decisions also proclaim the importance of protecting the public domain from undue incursion. ${ }^{54}$ Efficiency considerations also appear in decisions determining the proper breadth of protection for particular copyrighted works. 55 One recent Supreme Court decision has recognized that creative works inevitably borrow from and build upon prior creative works. 56 In view of the utilitarian purposes that U.S. courts frequently ascribe to copyright law,, 57 courts will probably continue to consider these other

49. See, e.g., CRAIg JoyCe ET AL., Copyright LAw 7 (3d ed. 1994) (reproducing the Statute of Anne's preamble, where the utilitarian rationale appears).

50. See Martha Woodmansee, The Author, Art, And The Market 35-56 (1994); see also Peter A. Jaszi, Toward a Theory of Copyright: The Metamorphoses of "Authorship," 1991 DUKE L.J. 455.

51. WOODMANSEE, supra note 50.

52. See, e.g., Sony Corp. of Am. v. Universal City Studios, Inc., 464 U.S. 417, 429 (1984); see also Wendy J. Gordon, An Inquiry into the Merits of Copyright: The Challenges of Consistency, Consent, and Encouragement Theory, 41 StAN. L. REV. 1343 (1989).

53. See, e.g., Campbell v. Acuff-Rose Music, Inc., 114 S. Ct. 1164, 1169-71 (1994) (free expression values); Keep Thomson Governor Comm. v. Citizens for Gallen Comm., $457 \mathrm{~F}$. Supp. 957 (D.N.H. 1978) (democratic values); Sony, 464 U.S. at $431-34$ (justice and personal autonomy values).

54. See, e.g., Feist Publications, Inc. v. Rural Tel. Serv. Co., 499 U.S. 340 (1991) (holding that the phone book is generally not entitled to copyright protection).

55. See, e.g., Computer Assocs. Intl., Inc. v. Altai, Inc., 982 F.2d 693 (2d Cir. 1992); Sega Enters. Ltd. v. Accolade, Inc., 977 F.2d 1510 (9th Cir. 1992).

56. See Campbell, 114 S. Ct. at 1167-68.

57. See supra notes $38-42$ and accompanying text. 
factors, along with the need to protect the authors to induce them to create and publish works of learning.

Boyle trenchantly criticizes the romantic entitlement rhetoric in copyright law and raises more than a few reasons to worry about the current direction of copyright policymaking. However, he provides less guidance than some readers might expect about how to weave justice, free expression, and efficiency considerations into copyright policymaking or about how this more balanced policy analysis would aid in the construction of a social theory of the information society.

Even so, Boyle persuaded this reader of the need for a social theory of the information society. Boyle aptly argues that copyright law must move beyond its current romance with authorship. To do so, it must reconstruct the concept of authorship in a way that will overcome the blindnesses of romantic entitlement theory. Success in this reconstruction effort would likely have broader effects on the law regulating information, for, as Boyle demonstrates so adroitly, courts applying other legal doctrines sometimes draw on romantic entitlement notions (pp. 81-107). Such a reconstruction is possible, for conceptions of copyright have changed over time and will continue to change. 58 Once we recognize that copyright is "a culturally, politically, economically, and socially constructed category rather than a real or natural one,"59 we can reconstruct it to reflect the values our democratic society chooses for it. Niva Elkin-Koren has recently suggested a conception of copyright that "perceives the creation process as an engagement in a social dialogue."60 She believes that some property rights in works of authorship "are necessary to secure the freedom to express oneself. Yet, the scope of rights should be adjusted to accommodate free dialogue."61 Like Boyle, she believes that we must redefine the private-public distinction in copyright in a way that will promote personal autonomy and democratic values. 62

58. See generally, Jaszi, supra note 50 .

59. Id. at 459.

60. Niva Elkin-Koren, Copyright Law and Social Dialogue on the Information Súperhighway: The Case Against Copyright Liability of Bulletin Board Operators, 13 CARdozo ARTs \& ENT. L.J. 345, 400 (1995). She points out that:

[p]ostmodernist scholars emphasize the significance of dialogue over meaning as the essence of the human cultural being and the struggle over meaning making as the essence of political action in postmodernity. Culture is thus perceived as an ongoing process of meaning-making through communicative activities, that is through social dialogue. This sphere is both constituted by the individuals engaged in it and constitute[s] them. Social agents enjoy different levels of power to fix and transform meaning depending on their Id. ability to access and control access to sources of signification and circulation.

61. Id. at $401 \mathrm{n} .290$.

62. See chapter 3; Elkin-Koren, supra note 60, at 391-99. 
Elkin-Koren points out that digital networked environments are well suited to promote personal autonomy and democratic values because they permit more decentralized forms of communication. She suggests that such environments "may allow more individuals to engage in a public discourse. Furthermore, [they] may allow for the expression of more views."63 She argues against imposing strict liability for copyright infringement on bulletin board system (BBS) operators and other on-line service providers: "The overall effect of a [strict] liability rule reinforces the existing centralized structure of power. Consequently, imposing liability perpetuates the predigitized distribution structures and prevents BBSs from achieving [their] potential for becoming a mecca of social participation and decentralization of power."64 Elkin-Koren does not argue that providers should be exempt from liability if they know of or encourage copyright infringement. ${ }^{65}$ She seeks to balance the legitimate interest of copyright owners with other social values. ${ }^{66}$

The interactive and dynamic nature of digital networked environments 67 makes Elkin-Koren's social dialogue theory especially well suited to enable the reconstruction of copyright law for the information age. An interdisciplinary consensus is emerging that digital technologies are having a profound impact on our conceptions of documents, and that documents themselves are changing in ways that those still caught in the print paradigm find difficult to grasp. 68 Some now conceive of documents as "social technologies," 69 that is, artifacts that provide "a powerful means for structuring and navigating information space ... [and] a powerful resource for constructing and navigating social space."70

In their essay, The Social Life of Documents, John Seely Brown, Chief Scientist of Xerox Corporation, and Paul Duguid explain the importance of social context in understanding documents:

63. Elkin-Koren, supra note 60, at 403.

64. Id. at 407.

65. See id. at 410; Sega Enters. Ltd. v. MAPHIA, 857 F. Supp. 679 (N.D. Cal. 1994) (holding a BBS operator liable for infringement because he encouraged up- and downloading of commercial video games).

66. See Elkin-Koren, supra note 60, at 410 (arguing against strict liability); REPORT OF the Working Group on Intellectual Property, National INFormation INFraSTRUCTURE TASK FORCE, INTELlECTUAL PROPERTY AND THE NATIONAL INFORMATION INFRASTRUCTURE 114-24 (Sept. 1995) [hereinafter WHTTE PAPER] (asserting on-line service providers should be strictly liable for user infringement).

67. See, e.g., Katsh, p. 125; Documents IN THE Digital Culture: A Report on A Workshop Held at tHE HaWaII INTERnational CoNFerence on SyStem SCIENCE (Jan. 1995) [hereinafter Digrtal Documenrs].

68. Katsh, p. 125; see also Richard A. LANHAM, THE Electronic WORD (1993).

69. LANHAM, supra note 68 , at 10.

70. John Seely Brown \& Paul Duguid, The Social Life of Documents, Release 1.0, Oct. 11,1995 , at 2. 
Seeing documents as the means to make and maintain social groups, not just the means to deliver information, makes it easier to understand the utility and success of new forms of documents. This social understanding should better explain the evolution of [the World Wide] Web as a social and commercial phenomenon. ${ }^{71}$

This social-context conception of documents appreciates the importance of audiences in relation to documents and to the sources from which authors have drawn material without losing sight of the value that authors provide. This approach overcomes the limitations of romantic entitlement theory which, as Boyle shows, tend to ignore social context and to treat documents as the author's work alone. The social-context conception of documents melds well with ElkinKoren's social-dialogue theory of copyright that, in turn, builds toward the social theory of the information society that Boyle aims to construct.

A countertrend to this approach can be found in the current effort to maximize the power of copyright owners - mainly in the hands of publishers - over all uses of their protected works, no matter how public or private in character. ${ }^{72}$ Insofar as this effort embodies a social theory of the information society, it would seem to envision the role of the citizen principally as a passive consumer of prepackaged information products licensed by copyright owners on whatever terms they choose to establish. ${ }^{73}$ "Shut up and shop" sums up the likely reaction of many on-line providers if customers show more interest in using the service to interact with one another instead of to make on-line purchases (p. 249 n.12).

The social-dialogue theory of copyright holds promise as an alternative to the copyright maximalist paradigm for the information society, one that envisions a more active role for citizens. It would also enable development of a fair-use rule under which no copyright liability would attach to such simple acts as sharing a poem with a friend. Shortly before his untimely death, the poet Joseph Brodsky expressed a widely shared sentiment: "[O]nce you've learned something by heart it's as much yours as the author's." 74 This does not mean that readers are entitled to commercially exploit the memorized lines in competition with the poet or her publisher, but it illustrates that private exchanges of information among friends make up part of our social dialogue that should be encouraged. The social-dialogue conception of copyright also would

71. Id.

72. See White PAPER, supra note 66; Pamela Samuelson, The Copyright Grab, WiRed, Jan. 1996, at 134 (criticizing WHITE PAPER).

73. See, e.g., Margaret J. Radin, Evolving Property Rules for Cyberspace, 15 U. PrTT. J.L. \& Coм. (forthcoming 1996) (discussing passive consumer conceptions of copyright rules).

74. Joseph Brodsky, English Lessons from Stephen Spender, NEw YORKER, Jan. 8, 1996, at 58,60 . 
be more consistent with the constitutional purposes of copyright law ${ }^{75}$ than the maximalist pay-per-use perspective.

\section{Moving Beyond the Print Metaphor}

\section{A. What Digital Does to Contract and Copyright Law}

Katsh's previous book traced the extent to which the print medium affected the evolution of important legal concepts. ${ }^{76} \mathrm{He}$ argued that modern legal consciousness:

is still demarcated and mediated by printed texts. Whether, for example, in the formation or interpretation of wills or contracts or in the review of court trials and legislative proceedings, the law's primary instrument remains the printed document. Wherever we turn, legal reality is largely shaped by the printed word. 77

In Law in a Digital World, Katsh follows through on these themes by looking forward to the transformations the electronic medium will bring to law and lawyering. Katsh understands that this is no easy task: "Our expectations about words on paper are so deeply ingrained that it is difficult to stand back and look at what a change in technology means for the manner in which we orient many of our relationships" (Katsh, p. 115). He sees the need for a dispassionate reconceptualization of the role of the lawyer for the digital age, and is brave enough to make some predictions for lawyers to ponder.

Katsh predicts, for example, that digital technology will bring changes in the substantive law of contracts. He cites the Statute of Frauds as an example of a contract rule that reflects the existing law's strong bias for written documents (p. 116). He points out that in the preprint era, oral statements were thought to be more authoritative evidence of the existence of contracts and their terms than writings because at the time memories were thought to be more reliable than written documents. ${ }^{78}$ The Statute of Frauds derives from an era in which written documents came to be more highly valued than human memory. Even though the Statute of Frauds currently is being reconsidered, ${ }^{79}$ our cultural preference for written or printed contracts remains strong, and lawyers will surely continue to make their livings drafting them. (1987).

75. See, e.g., L. Ray Patterson, Free Speech, Copyright, and Fair Use, 40 VAND. L. Rev. 1

76. See KATSH, supra note 7.

77. P. 8 (quoting Ronald K.L. Collins \& David M. Skover, Paratexts, 44 STAN. L. Rev. 509 (1992) (internal quotation marks omitted)).

78. See p. 116 (citing M.T. Clanchy, From Memory To Written Record (1979)).

79. Reconsideration of the rule arises from doubt about its continuing ability to deter fraud. See, e.g., U.C.C. Revised ARTICLE 2, § 2-2201 reporter's note 4 (Tent. Draft 1994) [hereinafter U.C.C. DRAFT]. Katsh does not mention this development, let alone suggest that digital technology caused it. 
How will digital technologies affect contracts? Katsh asserts that unlike printed documents, which are fixed and final, digital contracts will be dynamic and fluid (pp. 118-25). He says that while paper contracts "bind parties to an act[, t] he electronic contract binds parties to a process" (p. 129). Katsh predicts that lawyers who negotiate digital contracts will become involved in an interactive process of monitoring the relationships of parties to the contract and the ongoing evolution of their agreements (pp. 125-29). He expects groupware software to assist the digital lawyer in managing these evolving digital contracts (p. 125). Katsh predicts that contract rules will, as a consequence, become more focused on interpreting the parties' changing understandings and less on the static printed document embodying the parties' original understanding. 80

Modern contract law is less dependent on written documents than Katsh assumes. While the Uniform Commercial Code still requires written evidence of most contracts, ${ }^{81}$ it provides many default rules for interpreting contracts, such as those that allow trade usages, prior dealings between the parties, a course of performance under that contract, 82 and relevant oral statements made by the parties to supplement the terms of a writing to reflect the larger agreement of the parties. ${ }^{83}$ These rules, which effectively diminish the importance of writings in commercial law, predate digital technology. This suggests that it may be easier than Katsh realizes for contract law to evolve toward the dynamic, process-oriented model Katsh posits.

Digital technology may also cause contract law to evolve in ways that Katsh does not foresee. For example, a recent draft of rules to regulate the licensing of intangibles includes a proposed rule that would validate, as a matter of contract law, the making of automated contracts about digital information products. ${ }^{84}$ This rule contemplates a scenario in which a potential buyer or licensee of digital information would instruct an intelligent digital agent to search the network for a particular kind of information on terms within certain parameters. Somewhere out there in cyberspace, her agent would find and interact with the intelligent agents of sellers or licensors of the desired information. Through an exchange of messages, those agents would "negotiate" terms that, once agreed

80. Katsh, pp. 127-28. Katsh regards Ian Macneil's concept of relational contracts as a step in the right direction for digital contracts. See IAN R. Macneil, The New Social Con. TRACT (1980).

81. See U.C.C. \& 2-201 (1994).

82. See id. \$§ 1-205, 2-208.

83. See id. \$§ 2-202, 2-204.

84. UCC DRAFT, supra note 79, \& 2-2202. 
upon by the agents, would bind the persons for whom they are acting even though neither the seller-licensor nor the buyer-licensee was aware of the specific contract terms at the time the contract was made. Not all digital contracts, it appears, will be relationshipenhancing, dynamic, or fluid.

Writings are even more important in copyright than in contract law. The U.S. Constitution designates "writings" of authors as a subject matter about which Congress can legislate. ${ }^{85}$ Although U.S. copyright law now regulates far more than the printing and reprinting of books, the print metaphor continues to have importance in that body of law. 86 Copyright, says Katsh, "is in a difficult and highly challenging period not simply because copying is rampant and enforcement is difficult, but because even though it has not been widely recognized, the nature of our relationship with electronic information is vastly different from our relationship with print" (p. 219). Here, Katsh is even more correct than he realizes. ${ }^{87}$

One current controversy nicely illustrates the challenges that digital technologies pose for copyright law. The controversy concerns whether a temporary reproduction of a copyrighted work in the random access memory (RAM) of a computer - that is, a copy that will cease to exist when the computer is turned off - is a potentially infringing copy of the work. ${ }^{88}$ U.S. law defines the term copy as requiring a "fixation" of the work in a tangible medium. ${ }^{89}$ Is a RAM copy "fixed"? The legislative history of the copyright

85. U.S. Const. art. I, § 8 , cl. 8 .

86. The first U.S. copyright law protected only printed matter, such as maps, charts, and books. See, e.g., JOYCE ET AL, supra note 45, at 10. It now protects nonprint material such as motion pictures, photographs, and sound recordings. See 17 U.S.C. \& 102(a) (1994). Even so, copyright law continues to rely on many print-originated concepts. For example, it designates the owner of rights as the "author" and it relies heavily on the concept of "publication." 17 U.S.C. $\S \S 101$ (definition of "publication"), 201, 304.

87. Katsh apparently does not realize that copyright law has evolved beyond print-based concepts. In the early twentieth century, the Supreme Court thought that copyright protected particular artifacts, not all forms of representations of works. In White-Smith Music Publishing Co. v. Apollo Co., 209 U.S. 1 (1908), the Court held that a piano roll recording did not infringe the copyright in a printed musical composition. It decided that the piano roll was not a "copy" of the print artifact. Although Congress soon amended copyright law to make mechanical recordings of musical compositions an infringement, it was not until the Copyright Act of 1976 that copyright law focused on protecting all original works of authorship without regard to their particular form, as long as one copy of each work exists in a tangible form. See 17 U.S.C. $\$ 202$ (1994). Thus, the statute protects a "literary work" whether embodied in a printed book or in "books-on-tape."

88. Cf. Jane C. Ginsburg, Putting Cars on the "Information Superhighway": Authors, Exploiters, and Copyright in Cyberspace, 95 Colum. L. REv. 1466 (1995); Jessica Litman, The Exclusive Right To Read, 13 CARdozo ARTs \& ENT L.J. 29 (1994).

89. See 17 U.S.C. § 101 (1994) (definition of "fixed"). 
statute suggests not.90 Yet, a few courts and some policymakers insist that a RAM copy is fixed enough to infringe.91

The RAM copy infringement theory would seem to make it illegal to visit sites on the World Wide Web or to browse any other information in digital form. This idea appeals to those who wish to move the focus of economic activity in digital networked environments away from the supplying of individual copies to individual customers and towards the granting of access to digital information. The fact that every use of digital versions of copyrighted works involves the making of temporary reproductions in computer memory leads others to suggest that the reproduction right may not be viable as the central regulatory mechanism of copyright law in the digital environment. Perhaps we should reconstitute the exclusive-right provisions of copyright law to regulate the commercial exploitation of protected works. ${ }^{92}$ The very fact that questions are arising about the legal authority of copyright owners to control all uses of digital works supports Katsh's argument that the digital medium is changing the relationship between authors, publishers, and readers. Further changes in these relationships will arise with the use of technological forms of legal protection for copyrighted works. ${ }^{93}$

\section{B. Hypertextuality of Law}

Law is inherently hypertextual. ${ }^{94}$ Katsh gives the West key number system as an example of a legal hypertext. ${ }^{95}$ There is, however, far more hypertext in the law than this. Hypertext in law exists wherever a section of a statute refers to another section, wherever a regulation refers to its guiding statute, wherever a court opinion cites a prior case or legal treatise, and wherever a law review article refers to other texts. Links between or among chunks of text are the essence of hypertext. ${ }^{96}$ Hypertext has been with literate cultures since at least the Talmud.

90. See H.R. Rep. No. 1476, 94th Cong., 2d Sess. 62 (1976) (indicating that temporary storage in computer memory was not fixed enough to be an infringing copy).

91. See, e.g., MAI Systems Corp. v. Peak Computer, Inc., 991 F.2d 511 (9th Cir. 1993), cert. dismissed, 114 S. Ct. 671 (1994); WHITE PAPER, supra note 66, at 65.

92. See Jessica Litman, Revising Copyright Law for the Information Age, 75 OR. L. REv. (forthcoming 1996) (manuscript at 22-30, on file with author).

93. See Proceedings, On Technological Strategies for Protecting Intellectual Property in the Networked Multimedia Environment, 1 J. INTERACTIVE MulTIMEdia AssN. 1 (1994).

94. "Hypertext," a term coined by Theodor Nelson, describes the digital texts that enable users to create and follow links among different documents or components of documents. See TheOdor Holm Nelson, Literary Machines passim (1987). For a discussion of Nelson's legal and economic model for hypertext, see Pamela Samuelson \& Robert J. Glushko, Intellectual Property Rights for Digital Library and Hypertext Publishing Systems, 6 HARv. J.L. \& TECH. 237 (1993).

95. See p. 204. The principal function of the West key number system is as a navigational aid to hypertext.

96. See NeLson, supra note 94 , at $1 / 15$. 
Digital hypertexts have some unique properties. They make the contents of different documents seem to be part of the same document. They also make documents from different sources seem to be contiguous in a manner that print materials cannot achieve (pp. 204-05). Instead of "dead" links between one printed text and another, such as a cross-reference in each text to the other, digital technology enables creation of "live" links that allow the reader to "jump" immediately to the cited material. Using printed texts, a reader must get up and take yet another book off the shelf and thumb through it to find the same material.97 A hypertext designer also can "type" links so that potential users will know what kind of information to expect if she follows the link. ${ }^{98} \mathrm{In}$ a legal hypertext, statutory cites might, for example, be identified by a particular attribute, such as a color or font type. ${ }^{99}$ Links to other kinds of source materials might be assigned other attributes.

Katsh is among those who admire hypertext for the nonlinear reading experiences it makes possible (pp. 198-99). Printed texts tend to have a highly linear character: They start with this thought, then move to that, and continue with numerous other thoughts until the linear narrative ends. ${ }^{100}$ The author is the "authority" who dictates the reader's path through the text. Hypertexts, by contrast, are said to liberate readers because they permit readers to determine their own paths through texts and sometimes to create their own links (pp. 198-201). This changes the power relationship between authors and readers. By charting her own course through the text and creating her own links among its parts, the reader, in a sense, becomes the author of the text constructed from the raw material provided by the hypertext author. ${ }^{101}$ In the liberationist rhetoric of hypertext, readers throw off the chains of passivity that print has imposed on them and become their own masters, empowered to take a more active role in uses of texts. Katsh believes that hypertext "threatens to dismantle the print model even further by releasing the page from its binding and even by allowing a reordering of words, sentences, and paragraphs by each and every user" ( $p$.

97. The text describes a "live" link to two "dead" texts. One also may create "live" links to "live" information. For example, a link in a digital hypertext may connect to updated versions of a document. A link also may connect to a site that will generate, in real time, information tailored to the interests of the individual following the link based on that person's history of interaction with the site or other characteristics. Conversation with Robert J. Glushko, Chief Scientist, Passage Systems, in Ithaca, New York (Feb. 3, 1996).

98. See, e.g., Nelson, supra note 94, at 4/41-4/60. Katsh does not discuss link types.

99. The Bluebook rules that govern law review citation form include link-type conventions for legal reference materials. See, e.g., signals one type of link; $c f$. signals another. See Bluebook: A Uniform System of Citation 22-23 (15th ed. 1991).

100. See pp. 198-99; see also JAY David Bolter, WrItIng SPACE (1991).

101. See, e.g., Pamela Samuelson, Some New Kinds of Authorship Made Possible by Computers and Some Intellectual Property Questions They Raise, 53 U. PrTr. L. REV. 685 (1992). 
198). Katsh seems to regard the "page" as a concept that makes sense only in print (p. 205).

Katsh exaggerates the extent to which digital and print-based research experiences differ. When lawyers do legal research in a traditional print-based law library, they engage in a lot of nonlinear activities. They typically jump from one part of a judicial opinion to the midpoint of another, from a part of a case that cites a statute to the relevant subsection in the statute book, from there to a legislative history of the subsection, and so on. Tools, such as the West key number system, enable legal researchers to skip past most parts of judicial opinions to locate their golden nuggets. Many legal reference materials, such as Shepard's Citations, also were never meant to be read from beginning to end. Thus, ordinary printbased legal research often can be a multipath, active reading process. Law professors who ask their students to research a single issue based on a hypothetical fact pattern often discover that the students chart many different navigational paths through the same set of resource materials. The paths will vary considerably regardless of whether the students use only print materials, only digital materials, or a combination of both.

The continuing importance of the concept of pages is illustrated by the most extensive hypertext system ever developed, namely the World Wide Web. People put information on the Web by creating a "home page." A Web page is not an artifact of print conventions, but it has in common with print pages that it is a self-contained unit of separately indexable content. The digital environment thus has transformed the page concept, not made it obsolete. However, new conventions for locating content, such as the numbering of paragraphs of a text, will likely supplement the page concept in the digital environment. ${ }^{102}$

Katsh does not recognize how much control a hypertext developer exercises over the degrees of freedom users will have to make nonlinear uses of a hypertext. The developer determines how many links will be available, whether the links will be one-directional or bi-directional, and whether users will be able to make their own links. The extent of nonlinearity permitted by the hypertext will depend partly on the inclinations of the developer and partly on the nature of the application domain. Designers of virtual reality products will tend to maximize nonlinearity because getting lost in cyberspace can be fun. Authors of hypertextual reference materi-

102. Nonproprietary citation systems for legal information, including the use of paragraph numbers instead of page numbers for case citations, may soon emerge. See, e.g., Robert Berring, On Not Throwing Out the Baby: Planning the Future of Legal Information, 83 CAL. L. REv. 615 (1995). 
als, however, will heavily structure their works and allow users very little opportunity to cavort around in experimental ways. ${ }^{103}$

Besides, linearity may have abiding value for many kinds of legal materials, such as briefs, judicial opinions, and law review articles. Legal argumentation, by its very nature, proceeds linearly, taking logical steps from one idea to the next to a conclusion. Although Katsh never suggests that lawyers will stop making linear arguments, neither does he explore the future of linearity in digital forms of legal texts.

Forward-looking lawyers will learn to make use of digital technologies to facilitate the intertextual nature of legal analysis. One of these days, briefs submitted by lawyers to a court will contain links to the full texts of cited authorities. Lawyers will strengthen reply briefs by constructing links between portions of their opponent's brief and sources that undermine the opponent's argument. Judges will be able to pose questions for counsel before motion hearings by writing hypertext "pop-up" notes on the briefs. As these examples illustrate, hypertext can enable new forms of interactive experiences with legal texts. Thus, Katsh's prediction that hypertexts will effect the way lawyers organize and use information, and that this will affect how they conduct their business, seems sound.

\section{Macbeth Multimedia}

Katsh also predicts that digital technologies will enable lawyers to construct legal documents embodying graphics, sound, and video, as well as text, and this too will change the practice of law (pp. 133-71). Katsh does not use the term "multimedia," but he seems enthusiastic about the concept of it for future legal documents. Mixed media works have been difficult to create because of limitations of traditional media types. One cannot, for example, include motion picture clips in a printed book. In digital form, however, all information types - text, pictures, sound recordings, motion pictures, or video recordings - consist of binary digits. Thus, digital authors encounter far fewer impediments to mixing different types of information into one document. Digital multimedia creation requires a considerable amount of hard-disk storage space, good editing tools, and effective compression algorithms, but-with current technology, one can quite easily compile a document that includes text, pictures, sound recordings, and video.

103. A considerable amount of hypertext research focuses on designing easy-to-use navigational aids to help users avoid getting lost in hypertexts. See, e.g., Manfred Thuring et al., Hypermedia and Cognition: Designing for Comprehension, 38 COMM. OF THE ACM 57 (1995). 
Katsh predicts that digital multimedia will have a profound effect on lawyers, the practice of law, and law itself, by fundamentally changing the way lawyers represent, organize, and use information (pp. 133-71). The transition from the print medium to digital multimedia will, he thinks, prove as profound as the transition from scribal transcriptions to printed texts. Katsh observes that " $\mathrm{t}] \mathrm{he}$ cultural adaptation to printing involved more than confronting an information explosion in which more books were published and available. It required acceptance of new grammars, new modes of discourse, new styles of expression, new appearances and designs, and new assumptions about information" (p. 144). In order to take full advantage of printed books, people developed new literacy skills, namely, reading and writing. Our educational system continues to concentrate heavily on those skills. ${ }^{104}$ Katsh thinks that digital lawyers will need to acquire new visual literacy skills in order to exploit fully the opportunities that multimedia digital technologies will afford. ${ }^{105}$

Katsh perceives some "cracks" in the law's bias against visual information (p. 158). He points to the increased use of electronic recordings of images and sounds, sometimes known as "paratexts,"106 in court proceedings. Katsh views print as a distancing medium that "operates as a subtle but highly significant force in the process of making the judicial process appear to be objective, neutral and impersonal" (p. 164). He praises the use of visual information in legal materials because visual information is more compelling than print information. ${ }^{107}$

Katsh is correct that digital technology will enable lawyers to include more pictures, sounds, and video material in their documents. Multimedia is already being used to some degree in the presentation of forensic evidence in criminal cases and in computergraphics simulations of accidents and the like in tort cases. ${ }^{108}$ Hypertext briefs may include visual information, such as excerpts from videotaped depositions, which will have a different impact on decisionmakers than purely textual briefs do. Thus, Katsh may be

104. Katsh points out that reading and writing tend to be taught as though they were one skill, even though they are quite distinct. One requires consumption and the other creation. In contrast, we receive very little education in visual literacy skills, and we treat the viewing of art as a completely different kind of skill from the making of it. See p. 153.

105. If Katsh is correct on this point, law schools will need to offer multimedia courses.

106. For a discussion of paratexts, see generally Collins \& Skover, supra note 77 .

107. See pp. 159-62. The compelling nature of visual information, such as bloody gloves in a murder trial, sometimes causes courts to limit its use at trial. The prejudicial effect of such evidence may outweigh its probative value. The power of visual information does not arise from its inherent superiority as a form of information; rather it arises from the operations of human perception.

108. See, e.g., Henry H. Perritt, Jr., Video Depositions, Transcripts and Trials, 43 EMORY L.J. 1071 (1994). 
right that digital technologies will change lawyering practices, in particular, the way lawyers organize and present information.

Yet, Katsh underestimates the extent to which text will continue to play a prominent role in legal work. Text has many advantages: It is cheaper to construct than other information types. It requires far less computer memory, processing power, and bandwidth than digital pictures or video. Text is also easier to search and index than electronic pictures or video. The precision and recall rates for locating exact words in electronic databases approach one hundred percent. Because of this, a researcher's ability to find relevant documents by using a number of search words is quite impressive.109 Pictures and video, by contrast, are very difficult to search, unless someone has handcrafted descriptive labels for the pictorial information. Some progress has been made in the development of algorithms for searching the contents of digital pictures. 110 Nevertheless, the precision and recall functions of the search engines for visual information are poor as compared with searches of text. Someone who wanted to find a particular speech at a trial would do far better to search an electronic file of the trial transcript rather than an electronic file of the videotape.

Text will remain the primary form of legal communication for other reasons as well. Much of the prowess lawyers develop over time lies in an ability to abstract away from the messy complexity of real life and to construct more abstract representations of what happened in a manner that will facilitate resolution of disputes. If law is not as neutral or objective as many lawyers would like to believe, text nonetheless may contribute to a generally beneficial distanced neutrality in law. Text is also extraordinarily compact and well suited to the articulation of general legal principles, whereas visual information is rich in particularities of instances. In his enthusiastic embrace of multimedia, Katsh may have exaggerated the value of visual information in legal materials and underappreciated the abiding value of text. Would we really prefer judges to resolve disputes by constructing multimedia presentations? What precedential value would such an opinion have, and how would one cite it?

Robert Glushko, a hypermedia designer and consultant, warns his clients against "Macbeth multimedia"111 — that is, multimedia projects that overuse pictures, sound clips, and video in a way that obstructs rather than clarifies the message. Such presentations are

109. "Precision is the proportion of a retrieved set of documents ... relevant to a query, while recall is the proportion of documents in the collection ... relevant to a query ...." Teresa Pritchard-Schoch, Natural Language Comes of Age, OnLIne, May 1993, at 34.

110. Robert Wilensky, Chair of the Computer Science Dept. of the University of California at Berkeley, says that his department has developed "the world's best nude detector." Conversation with Robert Wilensky, in Wailea, Haw. (Jan. 3, 1996).

111. Conversation with Robert Glushko, supra note 97. 
"full of sound and fury, signifying nothing."112 For many application domains - including law - text will remain a highly useful, effective, and economically sound form of communication.

\section{Needles and Haystacks}

Katsh also considers the impact of digital technologies on the accessibility of legal information. He predicts that digital technology will enhance public access to legal information. This may reduce the public's need for lawyers and put lawyers in greater competition with other professionals (pp. 83-91). Katsh argues that digital lawyers may need to become proficient in other disciplines or to team up with other professionals in order to maintain a competitive edge (pp. 83-91). This would, of course, fundamentally change the nature of legal practice if it occurred on a large scale.

Katsh believes that digital technologies can lessen two kinds of distance between ordinary people and the law. First, it can lessen physical distance because people can more easily log on to a legal database than trek to law libraries. Second, it lessens "information distance," that is, the relative difficulty of finding the appropriate needle in the haystack of legal materials. Ordinary people can conduct a search in a legal database without knowing how to use the West key number system, Shepard's Citations, or the other complex legal information resources (pp. 57-62, 65-91). Using natural language search technologies, an ordinary person can formulate a question and receive responsive information (pp. 85-86). Those with access to the Internet and the World Wide Web also can access sites that contain legal information (p. 86). For example, people can access U.S. Supreme Court opinions at Cornell's Legal Information Institute site. ${ }^{113}$ At the Thomas Web site, they can access bills pending before Congress. ${ }^{114}$

Katsh is surely right that digital networked environments have enhanced public access to legal information, and that this trend will likely continue. He also may be right that lawyers whose work largely involves finding information in books for their clients may be put out of work as these materials go on-line. Most lawyers, however, need not worry. Digital technologies will not significantly reduce the information distance between ordinary people and the law as much as Katsh predicts. People hire lawyers because they believe the lawyers will know how to extract the right needle from the right haystack of legal information. This ability requires more than knowing how to use the West key number system; it also re-

112. William Shakespeare, Macbeth act 5, sc. 5.

113. Its Uniform Resource Locator (URL) is http:/www.law.cornell.edu.

114. Its URL is http://thomas.loc.gov/. 
quires a set of conceptual, analytic, and judgment skills that lawyers learn through complex pattern-matching exercises in law school and law practice. Few ordinary people possess these skills.

Besides, in some respects, public access to legal information may be more restrictive in the electronic environment than before. The major commercial legal databases restrict the classes of people who can access them (e.g., students of a subscribing law school). In addition, these services charge relatively high prices to individual users. Many print law libraries, by contrast, have long been open to the public for free. And print libraries have live librarians to aid user searches, whereas electronic databases do not. ${ }^{115}$

Katsh is not alone in hoping that digital technologies will enhance the ability of information consumers to find needles in the haystacks of large databases of information. ${ }^{116}$ Many computer scientists and software companies are working to develop software that will improve the efficiency of electronic searches. Unfortunately, digital technologies are not just part of the solution - they are also part of the problem. This society has been amassing digital information in such quantities that our haystacks now are almost unimaginably large and getting larger every day. ${ }^{117}$ Good software tools may help with needle detection in some domains, but in the domain of law, the best needle-detectors will continue to be smart, well-trained lawyers.

\section{CONCLUSION}

Boyle and Katsh not only predict imminent paradigm shifts ${ }^{118}$ in the law of information and in lawyering; they also aim to assist readers to leave behind the disabling concepts of the past and embrace concepts that will enable a better future.

Boyle aims to reconstruct the notion of authorship in order to facilitate more balance in copyright policy. No one who reads Boyle's book can fail to detect the pleasure he takes in a wellturned phrase. ${ }^{119}$ From this alone, it should be apparent that Boyle does not oppose authors' rights except to the extent that romantic notions about authorship lead to inefficient or unjust legal outcomes, as sometimes occur when we fail to appreciate fully the

115. Katsh discusses at some length why electronic legal databases cannot be considered "libraries." See pp. 65-75.

116. Information retrieval is, as a consequence, one of the key fields of computer science.

117. It is becoming common to speak of "terabytes" of information. See, e.g., Claire Mencke, The New America, INVESTOR's DAILY, Jan. 17, 1996, at A4 (discussing data storage difficulties with terabyte data collections).

118. For a discussion of paradigm shifts, see generally ThOMAS S. KuHN, THE STRUCTURE OF SCIENTIFIC REVOLUTIONS 174-210 (1970).

119. See, e.g., Boyle, p. 4 ("The human genome project is simply a large scale exercise in cryptography."). 
sources from which authors draw or the contributions of audiences (Boyle, pp. 59-60, 164-65). Boyle asserts that author-entitlement theory "has a clear element of existential truth" and that "it seems to work" (Boyle, p. 60). He strives to cure the blindnesses that romantic-entitlement theory has inflicted on copyright law. His book is more successful in showing the disabling effects of romantic-entitlement theory than in articulating a new, more enabling notion of authorship. Nevertheless he moves the relevant discourse along. This review suggests that the social-dialogue concept of the author, which depicts authors as contributors to social dialogue, along with their audiences and sources from which they draw, is a plausible candidate for the reconstituted author notion that Boyle's social theory of the information society requires. ${ }^{120}$

Katsh asserts that digital technologies will bring fundamental transformations to the law and law practice, and that today's lawyers ignore these transformations at their peril. A factor that may impede acceptance of his thesis by many lawyers is his unconventional mode of argumentation. Katsh discusses, in diffuse detail, various characteristics of digital technologies that may impact the law. He hopes that the cumulative effect of this discussion will persuade readers of the likelihood of fundamental change, even if there are reasons to question some of his individual points. ${ }^{121}$ Mainstream legal analysis tends to regard flaws in any part of an argument as reason to doubt the whole argument. When this review essay suggests that Katsh may exaggerate the transformative effect of hypertexts and digitized visual information for law and lawyering, it signals a skepticism toward Katsh's larger thesis. Yet, if one accepts the McLuhanesque notion that the medium is the message, one also should entertain the notion that the digital medium may bring larger changes to the legal profession than printoriented lawyers easily can perceive. Katsh deserves credit for writ-

\section{See supra notes 58-74 and accompanying text.}

121. Katsh identifies a number of characteristics of the electronic information environment that may affect law and lawyering: (1) digital information is less permanent and stable than print information; (2) digital information is more decentralized than print information; (3) digital information is more dynamic than print information; (4) digital information is less linear than print information; (5) digital information diminishes distance, in that documents stored in different places seem adjacent to one another; (6) digital information erodes other jurisdictional boundaries; (7) digital information is more difficult to authenticate than print information; (8) digital information can be searched in different ways than print information; (9) control over access and use, rather than the sale and distribution of copies, is the key focus of economic activity for digital information; (10) the digital medium enables the integration of more information types into documents; (11) the digital medium enables more interactive communication than print media; (12) the digital medium enables collaborative work; (13) the digital medium enables information to be networked in ways print does not; (14) the digital medium enables more continuous monitoring of relationships than the print medium; and (15) the digital medium places more value on sharing information than hoarding it. See pp. 50-59, 79-91, 95-107, 204-11. 
ing the first book that attempts to chart these larger changes and to equip lawyers to survive the transformation.

Boyle and Katsh rightly perceive a need for books that provide a social theory for the information society and that provide lawyers with insights about changes that digital technology may bring to their profession. Both wrote books they felt were needed, and neither was deterred from their ambitious projects by a fear of failure, though predicting the future is inevitably a perilous intellectual activity. Boyle at one point expresses the hope that even if his ambitious project failed, it would be "a large failure rather than a small one" (Boyle, p. 155). This review commends both books for their successes - and for failures that are large enough to make the books well worth reading. Both books advance our understanding of the complex challenges of information policy and digital technology for law and lawyering in the twenty-first century. The poet Rainer Maria Rilke once expressed the value of tackling seemingly unmanageable tasks:

What we choose to fight is so tiny!

What fights with us is so great!

...

When we win, it's with small things, and the triumph itself makes us small.

What is extraordinary and eternal does not want to be bent by us.

I mean the Angel who appeared

to the wrestlers of the Old Testament[.]

...

Whoever was beaten by this Angel

(who often simply declined the fight)

went away proud and strengthened

and great from that harsh hand,

that kneaded him as if to change his shape.

Winning does not tempt that man.

This is how he grows: by being defeated, decisively,

by constantly greater beings. ${ }^{122}$

122. Rainer Maria Rilke, The Man Watching, Selected Poems 105, 105-07 (Robert Bly trans., 1981). 


\title{
COMPUTER MEDIA FOR THE LEGAL PROFESSION
}

\author{
Eugene Volokh*
}

\section{INTRODUCTION}

This is a review not of a book, but of a set of communication media. The year 1995, we're told, was the year of the Internet. ${ }^{1}$ Anything as heavily hyped as the Net has been is guaranteed to have gotten overhyped, and many have become justifiably skeptical of claims about How Cyberspace Is Changing Our Lives Even As We Speak.

Still, there are indeed many cyberspace resources that are already useful to lawyers, law professors, and law students; and there are valuable opportunities for legal professionals to profit from creating more such resources. In this review, I want to briefly explain what the new communication media are, what their best specimens today seem to be, and how people can benefit both from using what's already out there and from creating new resources themselves. ${ }^{2}$

Cyberspace - which encompasses more than just the Internet - includes at least three different kinds of media:

Electronic Books, Bookshelves, and Libraries: The muchtalked-about World Wide Web is essentially a collection of electronic books, bookshelves, libraries, and other research tools. Each Web site is a collection of material that you can go to and read, like a book, but is generally free, accessible directly from your computer, and more easily searchable.

Electronic Newsletters: Just as you can subscribe to magazines or newspapers that will arrive in the mail, so you can subscribe to electronic magazines and newspapers that come in the e-mail. Like electronic books, though, electronic newsletters are cheaper to produce than their print counterparts and as a result tend to be available for free.

* Acting Professor, UCLA Law School (volokh@law.ucla.edu). My thinking in this area was significantly influenced by my participation in Trotter Hardy's cyberia-l@listserv.aol.com mailing list, and I'd like to thank all its members for their assistance, direct and indirect.

1. See, e.g., Amy Harmon \& Robert Burns, 1995-96: Review and Outlook, L.A. Times, Dec. 27, 1995, at D1.

2. I won't talk about how the new media can be useful in legal education; there's a lot to be said about that, but no room here to say it. 
Electronic Conferences: Here we come to the famous Internet "discussion lists" or "news groups"; conferences on non-Internet services, such as Prodigy, Compuserve, America Online, and, especially relevant for the legal profession, Counsel Connect, also qualify. These groups let one participant communicate (more or less through e-mail) with all the other participants, and can be fora for debate, for asking questions, for floating trial balloons, and for other things.

These new media - under optimal circumstances - can be considerably cheaper, timelier, and more flexible than their physicalworld analogs, and this means two things. First, it makes it possible for some of them to supplant the old media, at least to some extent. Thus, Cornell's LIIBULLETIN, which delivers abstracts of U.S. Supreme Court cases (and, if you like, the entire decisions) the day they come out, is a viable competitor to BNA's U.S. Law Week Supreme Court opinions service. LIIBULLETIN currently has 6600 subscribers. $^{3}$

Likewise, http://www.census.gov contains a vast amount of U.S. census data, which one would otherwise have to go to the library to get; 4 other Web sites house similarly valuable material. Many electronic conferences, though certainly not all, let you participate in thoughtful, substantive discussions with some of the best people in the field, often more productively and certainly much more cheaply than could happen at a traditional conference.

Second, and in some ways more intriguing, the medium's low cost and greater flexibility make possible publications that otherwise never would have seen the light of day. If only a few hundred people throughout the country want a certain sort of information for instance, instant updates to a casebook, or abstracts of articles on constitutional law, or a collection of material on an esoteric legal topic - the information won't get published. Printing and mailing it to subscribers, or distributing it to law libraries, costs too much. But online, the only serious cost is the editor's time - a nontrivial matter, but one that can be much less of a barrier.

3. E-mail from LIIBULLETIN to author (May 2, 1996). The U.S. Law Week people wouldn't tell me how many subscribers they had. Telephone conversation with BNA Customer Services Representative (Jan. 18, 1996).

4. The address - http:/www.census.gov - is something called a "URL," a Uniform Resource Locator. URLs tend to begin with "http:" (which stands for "hypertext transfer protocol"), followed by two slashes, the identifier of the computer on which the site resides ("www.census.gov"), and, optionally, more slashes and names further identifying the site. Thus, http://www.usps.gov/ncsc/lookups, mentioned below, resides on the "www.usps.gov" computer, in a file named "ncsc/lookups" (more or less).

Occasionally, you'll see addresses with names such as "gopher:/l ... " rather than "http://" - these are also URLs and can also be accessed from Web browsers. 


\section{WORLD WIDE WEB SITES}

\section{A. The Electronic Book (or Bookshelf)}

A Web site is a way for someone to make material available to anyone who has Internet access. Setting up such a site is like publishing a book, but generally a good deal cheaper both for the author and for the readers, assuming both already have computer hardware adequate to the task. ${ }^{5}$ There are no printing and distribution costs, and no publishers, bookstores, or libraries to be persuaded that it's worthwhile to print the book and stock it. Put the data on the Web site, and that's that.

For instance, as I mentioned above, the Census Bureau has put an amazing amount of statistical data on its $h t t p: / / w w w . c e n s u s . g o v$ site: population information arranged by state, by county, by race, by language spoken in household, by income, and by various combinations of these and many other factors. Of course, this information is listed in various print publications, but few of us have them in our offices. But if we have an office computer with access to the Internet and a so-called "Web browser" program (such as Netscape), the census site lets us get the information in minutes.

Likewise, the Library of Congress puts many recent legislative documents (for instance, the text of pending bills) at http:// thomas.loc.gov; the SEC puts the text of regulations and proposed regulations on $h t t p: / / w w w . s e c . g o v ;$ the FBI puts information from the Uniform Crime Reports on http://www.fbi.gov; and other government agencies put their material on sites of their own. ${ }^{6}$ A lot of this information changes quickly, so it might not even be easily available in print - the Web sites may be the only convenient and cheap places to get it.

For the last few years, most appellate courts have made their new decisions available online, many legislatures have put many of their state codes online, and some law reviews have created sites with the text of their recent issues. Various Web sites, such as Villanova University Law School's http://www.law.vill.edu and the Lawyer's Legal Research Index (LLR) site at http://www.llr.com provide access to this material. If you want, for example, the text of a recent Ninth Circuit opinion, you can go to one of those sites and view it, print it, or download it to a disk file. The LLR site even lets you do full-text searches of recent case law. Cornell Law School

5. This isn't an unreasonable assumption. Most law professors and many law students and lawyers have personal computers; those not already on the Net can get on for the cost of a modem plus about $\$ 20$ per month for an online service. Most law schools and many law firms have computers that can be set up for electronic publication, through Web sites or distribution lists. Even those without the right hardware can rent computer time fairly cheaply.

6. See, e.g., http://www.fcc.gov. 
maintains many legal materials, including some otherwise hard to get foreign texts, at $h t t p: / / w w w . l a w . c o r n e l l . e d u / s o u r c e . h t m l ;{ }^{7}$ there's also an impressive collection of international links at $h t t p: / / w w w . h g$. org. Today, probably the best index of all the law-related material online - which contains pointers to these and many other sites is http://www.findlaw.com.

Public interest organizations also use the Web to maintain clearinghouses of information that support their causes. For instance, the Second Amendment Foundation (http://www.saf.org) and the National Rifle Association (http://www.nra.org) have Web sites for anti-gun-control information. The Electronic Frontier Foundation keeps a Web site containing archives on cyberspace freedom and in particular on electronic censorship cases at $h t t p: / / w w w . e f f . o r g /$ links.html. The ACLU has a Web site at http://www.aclu.org; freemarket activists have one at http://www.free-market.com.

On a more practical note, http://www.usps.gov/ncsc/lookups will give you the ZIP-plus-4 for any address in the United States again, you can also get these numbers, or at least the first 5 digits, from a book, but few of us have that book in our offices. ${ }^{8}$ The http: $/ / w w w . s w i t c h b o a r d . c o m$ site contains over eighty-five million phone and address listings compiled from White Pages all over the country; you can search them by first name, last name, city, state, or any combination. Similarly, http://www.four11.com has a pretty good directory of people's e-mail addresses. The http://www.books.com site will let you mail-order books from a selection of over 400,000 - the equivalent of a print catalog, but bigger, easier to use, and more accessible. Finally, the http://www.cdconnection.com and $h t t p: / / w w w . c d n o w . c o m$ sites let you mail-order CDs from a selection of over 100,000, and at a nontrivial discount from store prices.

These examples illustrate the six advantages of online documents: They're (1) more accessible, (2) timelier, (3) cheaper, (4) easier to search, and (5) easier to copy into your own electronic documents; and, because of the cost savings, (6) the Web makes it possible to publish items that otherwise never would have been distributed publicly at all. It still takes time and money to put this material online, but much less than it would cost to print it and distribute it throughout the nation.

7. There is no need to worry about remembering the individual http: ... address every time you want to access a Web site; your Web browser will let you record the address the first time you access the site, and then will let you get back to the site just by clicking on the right line in the address list.

8. A tip: If you can remember only the top-level pointer in an address, in this case www.usps.gov, try just going to that pointer, http://www.usps.gov; usually you'll get a toplevel screen that will send you in the right direction. 


\section{B. What the Web Is and Why It's Called the Web}

We often speak of a "Web site" or a "Web page" as a physical object or a physical place, but a Web page is generally just a file on a computer that's directly connected to the Internet. At its simplest, it's only a bit more complicated than a WordPerfect document.

If you have an article, for instance, that you want your colleagues to be able to read, you can simply ask your Internet service provider to put the article on the provider's computer. My provider is UCLA Law School's computer services department, so if I want to put something up it'll be called $h t t p: / / w w w . l a w . u c l a . e d w /$ followed by the document name. Once this address is assigned, I can send an e-mail to my friends - or, for instance, post a message to an electronic conference - saying "If you want to read my article, look at http://www.law.ucla.edu/whatevernameischosen."

I might want to get more complicated than that. For instance, I might want to create a clearinghouse of information on freedom of speech and workplace harassment, an area in which I have done some research. I might want to put up copies of articles (both my own and others'), copies of relevant cases, the scanned-in text of some unpublished cases, and so on.

I wouldn't just gather these all into one document, because then someone would have to slog through the whole file to get the snippet he wants. Rather, I'd put each one in a separate file, a separate "Web page." Then, I'd set up a master page - perhaps called http: //www.law.ucla.edu/harass - that would contain a list of all my other pages; and inside the master page I'd put special markers that tell Netscape, or whatever browser the user is using, the addresses of those other pages. Whenever the user clicks his mouse on the name of a page, Netscape would automatically bring it up for him.

What's more, my document could point not just to my other documents, but to documents in others' collections, too. For instance, if I want to put a case on my page but the case already exists at some other site - for instance, on a Web page maintained by the court - I can just put in a link to that case. I don't actually have to copy the text onto my computer; I only need to enter the case's address.

This is why the Web is called the Web: It's a network of documents that contain both data of their own and pointers to other documents. Linking thus makes it especially easy to create compilations of existing information. You can create valuable things with the Web without actually writing a lot of text yourself. If you can find enough interesting material that's already on the Web, you can quickly put up an index page that can be useful to a lot of people. 
Web pages can be more sophisticated still. They can include graphics; they can prompt you for information and then pass that information to the computer on which they're running; they can automatically send e-mail, and do various other things. But the majority of Web pages are simply collections of data - the pages or the chapters of an electronic book.

\section{What's Currently Useful to Legal Professionals}

For legal professionals today, the Web is mainly useful for nonlegal research: As I mentioned above, there's a lot of government, scholarly, and current-events material available online. And there are good search tools that can be used to find this data, which I discuss below in section I.D. Law professors might still prefer to take advantage of their trained reference librarians, though the librarians themselves might end up finding the data on the Web. But law students and many lawyers don't have this luxury; for them, the Web may be the best place to start looking.

Unfortunately, today the Web is of limited use to legal professionals seeking traditional legal materials: cases, statutes, regulations, and commentary. Some such information - mostly the information created very recently, after some courts, legislatures, and law reviews began to publish their materials online - has found its way onto the Web, but the bulk of material important to lawyers, law professors, and law students has not. Putting it on the Web would be very expensive: LEXIS, Westlaw, and the CD-ROM manufacturers have invested in this process, but Villanova University and others who offer the material for free have not.

Of course, someone could set up a pay Web site and scan in the print material, or try to buy licenses from current players such as LEXIS. This, though, effectively would be LEXIS itself. LEXIS and Westlaw aren't implemented as Web sites, but they're basically the same things, though they had much higher startup costs than Web sites now have.

If LEXIS, Westlaw, and CD-ROMs didn't already exist, Web sites of statutes and case law, with all their limitations, would seem very promising: They'd provide free access and computerized searching for at least some material. But for law professors and law students today, LEXIS and Westlaw leave the Web sites in the dust. Even for cost-conscious lawyers, the best bet is probably to use CDROMs, and perhaps access Web sites just to get the latest material.

In years to come, more and more statutes, administrative materials, law reviews, and even treatises will go online; the case law databases will also become richer. But for now, the main uses of the Web for legal professionals are:

(1) Nonlegal research. 
(2) Free research on recent developments such as new cases and new proposed laws and regulations.

(3) Downloading the text of material that's available on the Web. The Web copies, unlike LEXIS and Westlaw printouts, generally don't have that annoying header information at the start of each page, and they also can be forwarded freely to electronic conferences and used in other ways that might violate a LEXIS or Westlaw contract. When I post the text of a new case to an electronic conference, for instance, I tend to download it from a Web site.

\section{Searching the Web}

Finding what you want on the Web isn't trivial, but it turns out to be easier than one might think. The new technologies increase information overload, but they also make available new tools that can help manage the overload.

There are two kinds of these tools available: topical directories and search services. Most Web browsers provide access to both; for instance, Netscape's "Net Directory" and "Net Search" - available from the first screen - each provide both a topical directory and access to several search engines.

The topical tools organize thousands of Web pages into various categories. For instance, at the first screen you get when you enter Netscape's "Net Directory," you'll see a list of general topical areas - art, politics and law, science, and so on. If you click on one of these areas, you'll see a list of subareas; if you click on one of the subareas, you might get a list of subareas within that. Eventually, you'll reach a list of Web sites devoted to a particular narrow topic. As of this writing, the major topical tools are Excite, Yahoo, and Infoseek; Excite is the default option in Netscape's "Net Directory," Infoseek is the default in Netscape's "Net Search," and Yahoo is available as an option in the "Net Directory" screen.

The topical services, then, are good if you just want to get the lay of the land. If you're looking for something more specific, you should use the search tools, which let you search for all Web pages that contain certain keywords. For instance, if you need the National Crime Victimization Survey results, you can select one of the search engines - Netscape provides access to several - and enter national crime victimization survey in the space provided. You'll get ten Web sites that seem related to this topic; if none of them looks helpful, you can ask for ten more Web sites, and so on.

The engines are fairly sophisticated. They generally let you search with and/or/but-not logic, and some have thesauruses that will search for synonyms of the phrase you entered. But they are also getting pretty good at optimizing even the simplest searches. 
For instance, if you just type in some keywords, most search engines will look for any sites that contain one or more of those keywords, but they'll show the sites containing more keywords first. Thus, if there are sites that contain "national," "crime," "victimization," and "survey," these will show up at the beginning; sites that contain only three of the words will show up later.

Excite, Yahoo, and Infoseek have keyword search mechanisms as well as topical directories, but as of this writing, the most powerful search facility seems to be Alta Vista, available from Netscape's "Net Search" screen.

\section{E. Opportunities for New Legal Publications}

What the Web currently offers to readers, though, is only half the story; the other half is the opportunities it presents to would-be writers. The new technology should make people ask: Is there some information that I could profit from making publicly available, that I couldn't make available before because of printing and distribution costs, but that I could make available now on the Net? In some areas people are seeing already that the answer to this is "Yes." Some examples:

Casebook Supplements: Casebooks invariably omit a good deal of useful material. New cases come out after the book goes to press. Relevant cases and articles are cut for space reasons. Also, readers' post-publication reactions sometimes lead the author to consider making changes. The yearly supplement allows for some additions, but at a fairly significant delay, and with considerable space limitations of its own. The author might instead, or also, create a Web page to supplement and update his casebook.9 Teachers using or considering the casebook can study this material and might suggest it to, or print it out for, their students. For an example, see http://www.law.uh.edu/faculty/CJoyce/cb2.html, a supplement to Joyce, Patry, Leaffer, and Jaszi's Copyright Law. ${ }^{10}$

A professor can set up a Web page relatively easily, especially with the help of a law school's computer-services staff. New material can be added as it becomes available. The profit to the author would come through increased consumer satisfaction, and potentially greater sales. Having such a Web page may eventually become a competitive requirement.

Information Clearinghouses: As I mentioned above, low cost and timeliness can also be valuable to public interest projects that want to set up information clearinghouses. A poverty law project,

9. My colleague, Daniel Lowenstein, author of DANIEL H. LOWENSTEIN, ELECTION LAW (1995), suggested this idea to me.

10. Craig Joyce et al, Copyright Law (3d ed. 1994). 
for instance, can set up a Web site with relevant statutes, forms, instructions, and litigation tips. Any lawyer who works in the field could then easily access this information. This can save the project money and further the cause at the same time.

Professional organizations that see service to the legal community as part of their mission might also contribute. A bar association, for instance, could set up a Web site housing a comprehensive set of professional ethics materials. Such a site can relatively cheaply ensure that all Internet-connected lawyers have free access to the various rules, opinion letters, articles, and the like - a good deal more information than most lawyers buy in printed form. Likewise, specialized bar groups can create topical Web pages; the Federal Communications Bar Association has a good one at http:// $w w w . f c b a . o r g$.

\section{F. Concerns: Readability, Reliability, Accessibility, and Continued Affordability}

People have pointed out several possible obstacles to the flourishing of Web-based legal information:

Readability: Online material is more cumbersome than print material. You can't easily read it while lying on the couch or walking down the hall. Even with the better quality of modern computer screens, it isn't as easy on the eyes. I've been working with computers since I was twelve, but I'd still rather read a law review article in print than on a screen.

But against these disadvantages one has to weigh the substantial benefits - including convenience - of computer text. It's easier to read part of an article online than to go to the library. Given the convenience, cost, and selection benefits, many legal professionals won't be daunted by the new technologies. We'll lose something by shifting to a large extent from print to electronic, but we'll gain more.

Reliability: By eliminating the intermediaries - editors and publishers - the Web also eliminates the checks they provide against errors. Anyone can put up anything they please, without any citechecking, verification of credentials, or guarantee that the data will be updated when it gets stale.

This leads to three problems:

(1) When an author moves his Web page to a new address, other Web pages that point to the old site might never get properly modified. When you try to follow the link, you get an error message.

(2) Some of the information on the Web, especially that found on personal pages, is untrue, greatly distorted, or incompetently gathered. To borrow a line from a recent science fic- 
tion book, "It's not called the Net of a Million Lies for nothing." 11

(3) Other information simply has slight errors, for instance scanning or transmission errors that were never caught because people don't hire citecheckers for free Web pages.

The upshot is that Web information, while useful, must be taken with a grain of salt. Problem (1) sometimes makes Web-surfing a frustrating experience, but at least doesn't raise the risk of incorrect data. Problem (2), however, means that information from unoffcial sites should be at most the starting point for further research. Finally, because of problem (3), even data from official sites might prove less reliable than that found in books backed by responsible publishers.

On the other hand, LEXIS and Westlaw contain computer glitches too, and we generally live with this without much trouble. In years to come, I suspect that there'll be both free services that provide access to unproofread public-domain material, and relatively cheap services that sell reliable access to proofread publicdomain material. For now, it's good to be cautious.

Accessibility: When people speak of how the Web makes material accessible to the public at low cost, they refer to that part of the public that has access to computers and Internet connections. Left out are those who can't afford these things, don't like these things, or are too busy to get these things and learn to use them.

Today, this is certainly a serious concern. If you publish online, there'll be some people you just won't reach. Though most law professors have Net accounts, some don't, and it seems that relatively few are comfortable using the Web. Likewise, many lawyers, like most laypeople, don't have Net access. ${ }^{12}$

In the coming years, though, legal professionals will probably become much more Net-connected, ${ }^{13}$ precisely because there's a good deal of material out there. Net access among the public at large is growing quickly, and lawyers are demographically the sorts of people most likely to join up - educated and relatively affluent. They tend to have personal computers already; they could go online for the price of a modem (if they don't already have one) plus $\$ 20$ a month for an online service.

Continued Affordability: Finally, some suggest that cyberspace materials won't remain free (or even cheap) for long. As the in-

11. Vernor Vinge, A Fire upon the Deep 228, 309, 431 (1992).

12. As of late $1994,58 \%$ of the 500 largest U.S. law firms had Internet access; as of early $1995,21 \%$ of sole practitioners and small firms had used the Net, and $45 \%$ had intended to use it in the next 12 months. See M. Ethan Katsh, Is Cyberspace Lawyer-Friendly?, TRIAL, Dec. 1995, at 36.

13. Cf. id. at $37-40$. 
fobahn becomes crowded, they argue, communication costs will rise; as it becomes easier to charge for material online, the providers of the really valuable material will begin to do so.

I agree that much of the most sought-after cyberspace content will eventually pick up a price tag, but I believe it will remain relatively cheap. Electronic publication creates genuine economies, and competition will cause providers to pass these economies on to users. The author of a new treatise certainly wouldn't put it online unless he could charge for access. But he needn't charge as much as he charges for the book version, because the online version saves distribution and printing costs.

The Web obviously has its weaknesses, and in years to come it may develop more. But the weaknesses aren't fatal, and, compared to other media, the Web still has many valuable advantages.

\section{E-Mail Distribution Lists}

\section{A. Electronic Newsletters}

Electronic books, like paper books, are best at storing more or less fixed data. They can be updated more easily than paper books, but they still aren't as good at communicating frequently changing information. People probably won't want to take the time to check a Web site every week, looking for new material.

That's where e-mail distribution lists - the electronic analogs of newsletters, newspapers, or magazines - come in. Just as Newsweek and The New York Times come right into people's homes, every week or every day, so distribution lists deliver information into people's e-mailboxes as it becomes available.

A great example is the Cornell Legal Information Institute's Supreme Court Bulletin (liibulletin@listserv.law.cornell.edu). To subscribe to it, you just need to send the message

subscribe liibulletin yourfirstname yourlastname

to the address listserv@listserv.law.cornell.edu. (As with all such listserv commands, the command should be the first and only line of the message; the subject line is irrelevant.) Then, whenever the U.S. Supreme Court hands down a decision, the syllabus of that decision will appear in your mailbox within a few hours. If you want the whole text of the case, you can just take the case number given in the syllabus and send the message

get UScasenumber (e.g., get US95-6789) to the same listserv@listserv.law.cornell.edu address. The opinions will arrive by e-mail within minutes.

This, of course, is an electronic counterpart of the BNA U.S. Law Week Supreme Court opinions service. It's not as easy to read, but it's quicker and it's free. It's free, of course, because Cor- 
nell is providing it as a public service; but Cornell is providing it as a public service because it really isn't that costly for them to produce - it takes a bit of time from some computer-services people, and a rather small fraction of the computer's horsepower. Cornell also produces LIIBULLETIN-NY (liibulletin-ny@listserv.law .cornell.edu), which sends out student-written summaries of key decisions of the New York Court of Appeals, usually within a few days of the decision. Similarly, the FCC puts out a daily digest of FCC actions, public notices, and other technical material (digest@info. fcc.gov).

For most electronic newsletters, the subscription instructions pretty closely follow those for LIIBULLETIN. If the address of the list is listname@a.b.c _ liibulletin-ny@listserv.law.cornell.edu, for instance - send the message:

subscribe listname yourfirstname yourlastname

(for example, "subscribe liibulletin-ny Eugene Volokh") to the socalled "listserv" address, listserv@a.b.c (in our example, listserv @listserv.law.cornell.edu). ${ }^{14}$ This is the command format expected by the most popular automatic list software, called "listserv."

From here on, I won't repeat this whole subscription information for most lists, but just give the list address. Some lists, though, use other subscription formats, such as "majordomo" format or manual subscription. When a list doesn't use the standard listserv format, I'll note this in a footnote.

While the LIIBULLETINs are cheap and quick alternatives to print media, electronic newsletters are best at providing information that might never even see print. A good example is material that's of interest mostly to academics, such as book reviews of scholarly works and abstracts of forthcoming articles. Printing and mailing these would cost a lot, and even a public-spirited law school might not want to foot the bill. Electronically composing and emailing the materials is much cheaper, though of course someone still must be willing to contribute the time to doing it.

Thus, the Law and Politics Book Review (lpbr-l@piranha. acns.nwu.edu), published by the Law and Courts Section of the American Political Science Association, sends out about one book review a month, each a few pages long. Law and Economics Abstracts distributes summaries of forthcoming law and economics articles; Corporate/Securities/Finance Law Abstracts does the same for its fields; Constitutional Law Abstracts, which I edit, sends abstracts of forthcoming law review articles on constitutional law. ${ }^{15}$

14. In some places on the Net, you might see a list's listserv address given as listserver@ a.b.c or listproc@a.b.c, but even then listserv@a.b.c usually should work, too.

15. Subscription to these three joumals isn't automated; to subscribe to any, send a message to sandy_barnes@journal.com indicating who you are and which journal you want. 
The University Law Review Project at Stanford also provides abstracts for many fields - to subscribe, visit http://dig lib.stanford.edu/lawcgi/join/add.cgi, or send an e-mail (contents irrelevant) to subscribe@thames.stanford.edu.

Electronic newsletters can also be useful for public interest organizations, which usually don't have a lot of money to invest in printing and mailing, and which don't want to reduce their audience by charging subscribers. Thus the Electronic Frontier Foundation puts out the EFFector! (effector-online@eff.org),,16 which contains news and opinion about cyberspace freedom issues. Outside the legal area, the campaign of Libertarian Presidential candidate Harry Browne set up announce-request@harrybrowne96.org,17 a distribution list for press releases, campaign information, and the like. Shortly afterwards, the Democratic Party created several campaign-related distribution lists of its own, news@democrats.org, news-digest@democrats.org, and events@democrats.org.18 The ACLU offers news@aclu.org, a general news service, and cyberliberties@aclu.org, a newsletter devoted to issues of freedom in cyberspace. ${ }^{19}$ Even individual activists are getting involved; Christopher Stamper's News Nuggets (nuggets@listserv.syr.edu) distributes Stamper's own politically conservative spin on the news to subscribers. ${ }^{20}$

Some people and organizations also provide more or less objective newsletters as public services. Jonathan Rosenoer writes and distributes Cyberlex, a monthly summary of recent legal events related to cyberspace, and Cyberlaw, a monthly essay on cyberspace law. ${ }^{21}$ Every other day, Educom, an education and technology institute organized by various universities, distributes edupage@ educom.unc.edu, a summary of cyberspace-related news events,

16. This is not a normal "listserv" list. To subscribe, you must send just "subscribe effector-online" - without your first name and last name - to listserv@eff.org.

17. This list has an unusual subscription format - to subscribe, send a message to announce-request@harrybrowne96.org containing the word "subscribe" in the subject line, not, as is usual, in the text.

18. This is a "majordomo" list, not the more common "listserv" list. To subscribe to a majordomo list, send a "subscribe listname" to majordomo@a.b.c, rather than a "subscribe listname yourfirstname yourlastname" to listserv@a.b.c. Thus, to subscribe to news@democrats.org, send just "subscribe news" - without your first name and last name - to majordomo@democrats.org.

Unfortunately, no single format will work for both kinds of lists. Some majordomo lists also accept messages that go to listserv@a.b.c, but even then they may insist that you not include your first and last name.

19. These are also majordomo lists - to subscribe, send just a "subscribe listname," without your first and last name, to majordomo@aclu.org.

20. This is a normal listserv list.

21. To subscribe, send a message containing your name and your institutional affiliation to cyberlaw@cyberlaw.com; the operator processes the subscriptions by hand. 
law-related or not. Edupage also comes out in French, German, Hebrew, Hungarian, Italian, Portuguese, Romanian, and Spanish.

Finally, on a frivolous note, I recommend:

(1) this-is-true@netcom.com, a weekly list of eight to ten funny stranger-than-fiction news stories. ${ }^{22}$

(2) mini-air@air.harvard.edu, a longish monthly from the editors of the Annals of Improbable Research, the science humor magazine.

(3) dilbert_list@internex.net, a monthly humorous column by the author of the comic strip Dilbert.

(4) lotd@world.std.com (Laugh Of The Day), a joke a day. Occasionally funny but uneven. ${ }^{23}$

(5) gunn56@inslab.uky.edu (The Internet Funnybone), a joke every few days. Again, occasionally funny but uneven. ${ }^{24}$

(6) Two edited electronic poetry magazines, RealPoetik (rpoetik@ listserv.wln.com), which specializes in free verse, and the Occasional Screenful (occasional-screenful@netcom.com), which specializes in formal verse. ${ }^{25}$

This Is True, incidentally, has 150,000 readers in over 100 countries. Despite being free, it has become a little business for its author, who has taken advantage of his online success to sell This Is True books and to license the newsletter to print newspapers. ${ }^{26}$

\section{B. Opportunities for New Legal Publications}

As with Web pages, the growth of electronic newsletters should lead legal professionals to ask: Is there some periodical information that I could profit from making publicly available through electronic newsletters, that I couldn't make available before because of printing and distribution costs? A few thoughts on some of the people for whom the answer should be "Yes":

Lawyers: Lawyers profit from paying clients, and a good way to get clients is to show others how much you know. That's why many lawyers write articles and put on seminars - to build their reputations among potential clients, in-house counsel, and other lawyers who might provide referrals.

22. A majordomo list, see supra note 18.

23. A majordomo list, see supra note 18.

24. This is another manually operated list; to subscribe to it, you should send any message that includes your full name to gunn56@inslab.uky.edu.

25. RealPoetik is a normal listserv list; the Occasional Screenful, edited by my brother and me, is a majordomo list - to subscribe to it, send the command "subscribe occasionalscreenful" (without your name) to listserv@netcom.com. Both have respectable circulations for poetry magazines; RealPoetik has over 1000 subscribers, and the Occasional Screenful has over 1650 .

26. John M. Glionna, Site Gags, L.A. Times, Jan. 3, 1996, at E1. 
The Net can be very handy here. A lawyer who specializes in a sufficiently unusual area can publish a newsletter that discusses current developments or provides helpful tips. It need not be long; indeed, many readers might prefer it short. Of course, it will take a good deal of the lawyer's time to produce something that readers will appreciate, but many people would be willing to occasionally invest the time if they could avoid the substantial out-of-pocket mailing and printing costs. And while a one-page newsletter on cheap paper might look unprofessional, a several-paragraph e-mail looks just fine.

Jonathan Rosenoer, who writes Cyberlaw and Cyberlex, says he's gotten a lot of professional benefit from his work, both direct (new business) and indirect - media exposure, invitations to speak at conferences, and other things that can lead to new business. $\mathrm{He}$ has over 1200 subscribers, his service has been licensed to America Online, and his columns are reprinted regularly by a number of computer user group newsletters. ${ }^{27}$

Advocacy Groups: Advocacy groups succeed by communicating their ideas to as many people as possible and by raising money, which in turn allows them to communicate still further. Electronic newsletters can help them do both of these things.

An electronic newsletter lets the group distribute facts and arguments that support its agenda, information about news events that might be of interest to its supporters, and details of its latest victories. Certainly the group's press releases to the traditional media should go to the electronic distribution list, too - after all, it's essentially free. The Electronic Frontier Foundation's EFFector! mailing list, described above, is an example, but non-cyberspacerelated groups sometimes do the same.

In print or electronically, advocacy group newsletters in large measure preach to the converted; but after all a big part of a preacher's job is precisely to make sure that the converted stay converted, and perhaps even become more devout. By keeping in touch with its members and sympathizers, the group can increase their willingness to contribute money. A request for contributions that follows a dozen substantive informational mailings shouldn't offend anyone. The request even might ask people to reply with a name, credit card number, expiration date, and amount. ${ }^{28}$

Legal Academics: Academics profit by having people hear about their work and by hearing about others' work that relates to

27. Telephone conversation with Jonathan Rosenoer (Jan. 16, 1996).

28. The legal defense fund for Philip Zimmermann, a cryptographer who is being investigated for possibly violating export control laws by making one of his programs publicly available, did something like this, and apparently got quite a few donations this way. Robert $J$. Ambrogi, Empowered or Enslaved?, Law OfFice Computing, Dec./Jan. 1996, at 37, 38. 
their research interests. The Law and Economics Abstracts and Constitutional Law Abstracts services mentioned above show how electronic newsletters can help academics on both fronts: They make it easy for academics to publicize their new works to their colleagues - often many months before those works go to print and they make it easy for them to keep up on the new scholarship.

In my view, every area of the law should have its own Abstracts newsletter. Newsletters aren't hard to set up, and enterprising academics can do themselves and their colleagues a favor by creating them. Law librarians can help out with this; linking readers and writers is, after all, the essence of their job.

Academic organizations with a bit more time, money, or student labor, such as institutes specializing in particular areas of the law, could perform a public service and spread their fame by publishing brief newsletters devoted to recent legal events. They could even download important recent cases from public Web sites and distribute them to their subscribers. LIIBULLETIN-NY is a good prototype; academics applying the same model can spread news of recent developments in poverty law, indigent criminal defense, and the like.

In many areas, professional print publishers already provide such services, and that may be the best solution; though print newsletters cost money, the profit motive might translate into higher quality. Other areas, though, might be underserved.

Publishers: Finally, even publishers of traditional legal materials can profit from going online. They'll still want to charge for the service, but they could charge less and publish in a timelier fashion. Online distribution does increase the likelihood of unlawful copying, but the benefits to publishers - coupled with the competitive pressure from free or cheap online services such as LIIBULLETIN or LIIBULLETIN-NY - should in many càses outweigh the costs. And web sites can also be good promotion for other material. American Lawyer Media's California law site, http:// $w w w . c a l l a w . c o m$, is an interesting example: It provides free access to some news and analysis stories from ALM publications, as well as free access to recent California and Ninth Circuit case law, to all subscribers to the Recorder - an ALM publication serving the San Francisco area. Nonsubscribers who are outside the San Francisco area can get access to the web site for $\$ 60$ per six months; nonsubscribers within the San Francisco area, however, would have to subscribe to the Recorder.

\section{Differences Between Electronic and Print Newsletters}

I draw an analogy between electronic and print newsletters, but some differences are worth considering. Electronic newsletters are 
a new medium. They look different and people read them differently. What's effective communication in one medium may not be effective in another.

I'm not aware of any serious studies of how to communicate well through an electronic newsletter, and the medium is probably still too young for us to have any definitive answers. Still, I want to offer a few tentative observations.

One Story Per Issue: Electronic newsletters, I believe, work best when they distribute one story per issue - for instance, one article every few days, rather than ten articles in a single monthly issue. People have relatively limited online attention spans; they often get their e-mail at work, where they might have only a few minutes to read it. They might take the time to read one story. Presented with ten stories, though, they might skim over one or two, and skip the rest. ${ }^{29}$

Having one story per issue is also convenient for other reasons. For readers, it's easier to forward a single-story issue to interested friends or to an electronic conference, or to save it to an e-mail folder. For distributors, especially distributors of timely material, it may be better to start thinking in a distribute-when-you-can mode rather than a wait-until-the-next-issue mode.

Of course, one shouldn't overdo things: If you send issues out too often - say, one or more a day - the subscribers might feel flooded, even though each issue is only a few paragraphs long. Conversely, a newsletter with five separate one-paragraph blurbs is unlikely to tax the reader's patience. But aside from these extremes, individual stories seem more effective than compilations.

Visual Presentation: E-mail is harder to read than print, and authors ought to compensate for this. A few tips:

(1) Length: Keep the message short. I'd guess that few e-mails that are longer than two or three screens get read in their entirety.

(2) White Space: Use lots of white space. Skip lines between paragraphs. Indent the first line of each paragraph. Skip two spaces after each period.

(3) Paragraphs: Keep each paragraph short, five or six lines at most. Don't be afraid of using single-sentence paragraphs; though frowned on in print, they may be necessary in e-mail.

(4) Formatting: Keep each line shorter than seventy characters; your e-mail program probably has a line-length setting that will do this automatically. Some programs let you fit more characters on a line, using proportional spacing, but you shouldn't use

29. Of course, subscribers could save the e-mail and read one story every couple of days, but my sense is that many people don't like doing this - they want to process their incoming mail and get it out of the way. 
this feature - if your subscribers use a different program, then your long lines will come out hard to read.

(5) For the same reason, don't use any special formatting features - italics, boldface, colors, special characters - that your e-mail program provides. (In time, this may change, as standards develop.) If you want to emphasize something, embedding a word between *asterisks* has evolved as a convenient eyecatcher.

(6) When you make a complicated point - for instance, when you articulate a multipart test or a multipart argument - use bulleted or numbered lists.

\section{Discussion Groups}

\section{A. The Electronic Conference}

The basic principle of an electronic conference is that any of the hundreds or thousands of participants can send a message to all the others. Any recipient can then respond, and the response will also go to all the other participants. The result is an online conversation, much like a panel discussion at a physical conference, but without expensive airplane tickets.

Discussion: Thus, if you have an interest in the law of government and religion, you can subscribe to ReligionLaw (religionlaw @grizzly.ucla.edu), an Internet electronic conference that I operate. Once you've subscribed, you can send a message to the religion law@grizzly.ucla.edu address - not the listserv@... address - and the host computer will distribute the message to all the conference subscribers. One or more of them might respond; if enough people jump in, an interesting discussion can start up.

These discussions can be valuable in several ways. Most obviously, they might bring up some arguments that one hadn't really focused on before. They can also serve as news sources; many developments in the cyberspace law area I first learned about online rather than through the traditional media.

Beyond this, a window into the thoughts of ones' colleagues has value even if one has heard and rejected those views before. The very fact that smart people make a particular argument with a straight face might lead us to take that argument more seriously, to confront it more thoroughly when we write a brief, teach a class, or write an article.

Much of what legal professionals do is guided by what they see as the unspoken norms of their field: Argument $A$ is respectable; argument $B$ isn't even worth mentioning. Unfortunately, we sometimes err - we dismiss an argument that we should have addressed more closely. Frequent informal contact with one's colleagues can help dispel these misconceptions. 
Research: You can also use the conference as a research tool. For instance, computer-based legal resources are ill-cataloged and constantly growing; before writing this article, I asked people on Cyberia-L (cyberia-l@listserv.aol.com), a list devoted to the law of cyberspace, if they knew of any valuable resources I might have missed, and they responded with many good suggestions. On LawProf (lawprof@chicagokent.kentlaw.edu), a list inhabited by over 700 law professors, people often ask questions about how other law schools set up their curves, assign credit for law review tasks, and so on.

Likewise, people often use conferences for guidance on substantive legal questions. People ask cyberspace law questions on Cyberia-L and copyright questions on CNI-Copyright (cni-copy right@cni.org). At least one person usually answers, either "on-list" - by posting the reply to all subscribers - or "off-list" - to the questioner directly. A patent lawyer I met through Cyberia-L sometimes asks technical questions on science-themed conferences; on several occasions, the answers have led him to patent-invalidating prior art. ${ }^{30}$ Obviously, no one with any serious interest in a question should take the answers of conference participants as gospel, but these answers often provide good departure points for further research. Finally, conferences are good places to test article ideas. I've often gotten interesting counterarguments and supporting arguments this way.

Publicity: Because conferences contain a ready audience of people interested in a topic, they are good tools for publicizing matters related to that topic, such as a symposium your school is putting together or an article you've written and of which you're offering reprints. People tend to frown on blatantly commercial publicity, but flyers for public-spirited or nonprofit enterprises are generally readily accepted.

When I finish a new article, I always post offers of reprints, or even prepublication drafts, in online conferences. For my most recent article, this led to over seventy requests, and that's seventy people who are likely to actually read the piece.

Schmoozing: Finally, conferences are also good places to meet others in your field and either impress them or persuade them that you're a fool. This can be particularly valuable (or harmful) to junior academics, and, particularly on Counsel Connect, to lawyers who are trying to get business. Especially when only a few hundred people throughout the country work in a particular area, it's good

30. E-mail from Bruce Hayden to author (Jan. 7, 1996); see also Electronic post to $h$-law @msu.edu (a legal history conference) (Jan. 26, 1996) ("My profound thanks to [conference members who responded to a question].... [A]n inquiry posted here is worth easily a week of nosing around a library."). 
for the field if these people get to know one another and get a sense for each other's qualities and interests.

Participant Quality: All this works only if the list includes knowledgeable people who respond to ideas and answer questions. This varies widely from list to list. Many of the top cyberlaw professors in the country participate in Cyberia-L. ReligionLaw gets posts from many of the most prominent writers on the law of government and religion. FirearmsConLaw (firearmsconlaw@ssiinc .com) has some of the top Second Amendment scholars, though rather heavily biased towards the anti-gun-control side. CNICopyright has a number of sharp copyright people. On the other hand, a list I set up on free speech law called CLSpeech (clspeech @ftplaw.wuacc.edu) lies mostly dormant - while it has some good people on it, questions often go unanswered, conversations peter out after one or two posts, and weeks can go by without a message.

In sum, with electronic conferences, you can:

(1) Participate in and listen to online discussions.

(2) Keep up with the news.

(3) Get a sense of the currents of colleagues' opinions.

(4) Find answers to questions.

(5) Float trial balloons to get an early reaction to an idea.

(6) Publicize relevant events.

(7) Simply enjoy chatting about interesting issues.

(8) Get to know others who work in your field.

I'm an addict - I'm on over a dozen conferences, including four I've founded (ReligionLaw, CLSpeech, FirearmsConLaw, and FirearmsReg). But even less cyber-hooked legal professionals can find one or two conferences on matters of interest to them.

\section{B. The Mechanics of Conference Participation}

Before I go further into the medium's costs and benefits, a few technical aspects of electronic conferences are worth explaining. First, while I speak generically about "electronic conferences," they actually come in three different flavors:

Internet Discussion Lists: These conferences work via e-mail. When you send the required subscription request to a particular Internet address (the so-called "listserv address"), you'll be added to the list of subscribers. Then, whenever you send a message to another address (the "list address"), that message will be passed along to every subscriber. When you reply to a message, your reply will also by default go to the whole list.

Thus, to subscribe to ReligionLaw, you'd send the message subscribe religionlaw yourfirstname yourlastname 
to the address listserv@grizzly.ucla.edu. ${ }^{31}$ Thereafter, to send a message to all the subscribers, you'd send it to religionlaw @grizzly.ucla.edu. The similarity between the two addresses isn't coincidental: As a general rule, a list called $x @ y . z$ would require you to send a "subscribe $\mathrm{x}$ yourfirstname yourlastname" command to listserv@y.z — as with the distribution lists described in Part II and then to send messages to $x @ y . z$. Some lists have different subscription instructions, but this model (the "listserv" model) is the most common.

If you want to stop getting messages from the list, you'd send unsubscribe religionlaw

to the same listserv@grizzly.ucla.edu address. For most lists, you may also tell the software to send you each day's messages in one combined message; the command is

set listname mail digest

To turn off messages temporarily - say, when you go on vacation

- send the command set listname mail postpone

To turn them back on, send the command

set listname mail ack

Again, though most lists understand these commands, some use a different syntax. The command "help" will usually get you a brief description of all the permissible commands.

Internet Newsgroups: For years, the main vehicle for most discussions on the Net has been the newsgroup. Rather than arriving in your mailbox, newsgroup messages go into a separate place on your local network, where you can read them from your computer using a "news reader" program. Some people, especially those whose e-mail enters through their office network, dislike this; they find the need to run the news reader a bit of a bother. Others prefer it because they don't want to be interrupted by conference email, and because a news reader makes it easier to ignore those conversations in which they aren't interested.

Currently, the overwhelming majority of discussion of interest to legal professionals takes places on discussion lists, not newsgroups. The one group with quality legal discussion is misc.int-property, which focuses on intellectual property. Three other legal newsgroups, misc.legal, misc.legal.computing, and misc. legal.moderated are generally frequented by laypeople, not by lawyers or academics. I mention newsgroups here mostly to clarify the difference between them and discussion lists - many people get the two confused.

31. The "subscribe" command should be the only line in the body of the message. 
Non-Internet Dial-In Services: Finally, some electronic conferences aren't on the Internet proper, but are rather on "dial-in services," such as Prodigy, America Online, Compuserve, or, most important for our purposes, Counsel Connect.

When people say something is "on the Internet," they generally mean that it's accessible from any other Internet site. If you and I are on the Net, I can send you an e-mail message. If your Web site is on the Net, I can use Netscape to access it. If your electronic conference is on the Net, I can access it from my computer.

This isn't true of discussion groups on, say, Prodigy. Prodigy users can dial in to the Prodigy computer, access its discussion groups, and talk to other Prodigy users. But they can't talk in those discussion groups to America Online users or to people - such as most law professors - who have a direct Internet connection. Prodigy, AOL, Compuserve, and Counsel Connect users can access Internet discussion groups, because those services let their customers reach the Internet. But because the services don't let Internet users access the service's computers, discussion groups on each service are limited to customers of the service.

Perhaps because of this, legal discussion groups that would be of value to legal professionals haven't really thrived on those services. (Compuserve's LAWSIG discussion area, and especially the lawyers-to-lawyers subforum, seems to be a slight exception.) But they have thrived in a big way on one special lawyer-only service, Counsel Connect.

Counsel Connect: Counsel Connect costs considerably more than most online services. The basic rate is $\$ 89$ per month; that falls to $\$ 39$ per month if one connects to it in a special but somewhat cumbersome way. Nevertheless, Counsel Connect had 35,000 subscribers as of April 1996, up from 18,000 in April 1995.32

This service may be worth its price tag to many lawyers because it can (1) lead them to new business and (2) connect them with lawyer-specialists who can provide off-the-cuff advice about particular legal issues. Counsel Connect's software provides special mechanisms that link in-house counsel with outside lawyers: Corporate counsel can anonymously post legal questions for outside lawyers, and if an answer is impressive enough, business can be done.

Counsel Connect also hosts many special-purpose discussion groups, some quite lively, others rather dead. Most that I've seen have pretty thoughtful and substantive conversations. I don't know how much business the typical Counsel Connect user gets from the

32. E-mail from Mark Obbie of Counsel Connect to author, Apr. 23, 1996, and Apr. 24, 1996. 
service, but I do know several people who have indeed found clients in this way. ${ }^{33}$

I've found Internet discussion lists to be more convenient than Counsel Connect, especially because I get my Internet messages without having to dial in anywhere. Discussion-list posts come directly to my e-mailbox, so I can retrieve them in a few seconds; reading a $\mathrm{CC}$ conference takes some time while my computer is dialing up $\mathrm{CC}$, and accessing each message or switching between conferences takes longer, too. CC even seems slower than many dial-in Internet providers, such as Compuserve or Netcom. On the other hand, some prefer the way Counsel Connect organizes its posts; they think the CC display format makes it easier to sift the interesting material from the irrelevant.

\section{Conference Quality}

How useful a conference will be to you turns on several factors:

(1) The number of messages that appear on it every day.

(2) The number of frequent participants who are knowledgeable, articulate, and willing to constrain themselves to the conference topic.

(3) The number of people who might not participate often, but who could answer your questions if you ask them.

These factors roughly correspond to the various diseases of electronic conferences. The worst, the "dreck deluge," comes when there are lots of messages, often twenty or more a day, and most of them are stupid or off-topic. In the mild form of this disease, "low signal-to-noise," the messages aren't very good but there still aren't too many. If ten messages arrive each day, six silly and four interesting, you still might derive value from the list, especially once you learn which messages you should delete unread based on their subject lines or their authors.

At the other extreme, many conferences are "dead" - no messages for weeks on end. Many of them are both dead and unresponsive: If you ask a question, you get no answers, or at least no useful answers. These conferences aren't much use, but they aren't much burden either.

Conference operators can do three things to try to cut down on bad posts:

Limit Access: Internet discussion lists can be set up to allow the list operator to screen each subscription request. Only law professors, for instance, can join the LawProf discussion list. I limit the CLSpeech, FirearmsConLaw, and FirearmsReg lists to people who

33. See Eugene Volokh, Technology and the Future of Law, 47 StaN. L. REv. 1375, 1402 n.154 (1995). 
do research in the relevant areas or at least seem well-versed in the subject.

Screening creates extra work for the operator. He must check each subscription request and, if necessary, question the subscriber about his bona fides, a sometimes unpleasant chore. The typical list, however, receives only a few subscription requests per month, and the work tends to be concentrated during the list's first few days.

Moderate: The operator also can screen each message before it's forwarded to all the subscribers. Most operators are pretty liberal about what they pass along; they tend to screen out only "flames" (personal insults), "spam" (advertisements that are posted indiscriminately to lots of groups), kooks, and errors, such as messages posted to the list but meant for only one person. Operators also can weed out repetitive material as well as messages that stray off the conference's topic. Moderating a list takes some time; Mary Brandt Jensen, who co-moderates the CNI-Copyright discussion list, tells me that moderating it has generally taken about fifteen minutes a day. ${ }^{34}$

Informally Shepherd: Finally, an operator might act informally. When a discussion veers off-topic, he can send a warning to the participants or to the whole conference. When someone insults another participant, the operator can come to the victim's defense. Many offenders willingly return to the rules, and other conference participants tend to defer to the operator's lead, largely because they, too, want the conference to stay polite and on-topic. In my experience, these sorts of informal controls have worked fairly well.

Some conferences have consciously chosen to remain unconstrained. They often lose some subscribers who dislike the high volume and the relatively high level of junk, but other subscribers have a greater tolerance for high traffic and are willing to invest the relatively little time it takes to delete the off-topic messages. I've often wished Cyberia- $\mathrm{L}$ had a moderator, but it remains a valuable resource.

Conference operators can also do some things to attract more good posts, not just fewer bad ones. A good operator can keep an eye out for interesting discussion topics or recent developments. When traffic dies down or veers in an off-topic direction, he could start some on-topic threads. An operator might contact top people in the field and encourage them to join. It helps, of course, if he can assure them that traffic is moderate and that most of it is intelligent and on-topic.

34. Conversation with Mary Brandt Jensen (Jan. 18, 1996). 
Finally, in my view - a view not shared by all - a conference operator should define the conference topic narrowly, even if it means excluding some relevant related topics. For example, though general discussions about the Free Speech Clause may be relevant to a conference on education law, they should probably be excluded. The participants on the conference might be education law experts, but they probably aren't experts on free speech theory. The free speech theory discussion will probably not be very good; it will probably end up repeating what most participants have already heard elsewhere; and it's quite unlikely to resolve issues that constitutional law experts have debated for decades. Likewise, on the ReligionLaw list, the rule is no discussion of theology as such or of the philosophy of religion and law, even when these points are relevant to a question about the law of government and religion. They might be relevant, but discussing them probably won't be very useful.

Choosing a Conference: To choose a good conference, start by subscribing to those whose subjects interest you. I list some in the appendix; http://www.lib.uchicago.edu/cgi-bin/law-lists contains a master list that's searchable by subject. Then, you should:

(1) Listen in for a week or so to get a feel for the type and quality of discussion.

(2) Get used to deleting messages unread if you don't find their subjects or authors interesting.

(3) Switch to digest mode the conferences that seem interesting but too high-traffic for you to read each message as it comes in.

(4) Unsubscribe from the conferences that seem useless. You'll probably leave some conferences and end up staying with one or two active ones as well as a few relatively quiet ones (which are neither a great benefit nor a great cost).

New electronic conferences usually take a few weeks to settle down. There's often an initial surge of activity while enthusiasts let out what they've been carrying around inside them for months or years; and there's often a lack of consensus about what the topic of the conference really is. After a few arguments and after several messages from the list custodian explaining the topic, things usually quiet down. Don't judge a conference by the first few frenetic weeks.

\section{Tips for Conference Participation}

Curiously, on all the conferences that I've seen, only ten to twenty percent of the subscribers ever post messages; the remainder "lurk," reading messages without posting any themselves. This seems to be something of a testament to the medium's quality: a lot 
of people apparently find the conversations worth reading even if they're not the ones talking.

If you decide to talk, you may want to keep in mind a few basic guidelines:

Formatting: The same concerns that I mentioned when talking about electronic newsletters apply here. Keep the message short, keep the paragraphs short, use lots of white space, avoid special formatting features, and use more general formatting gimmicks such as bulleted or numbered lists.

Also, stick religiously to standard capitalization and spelling rules. Because e-mail is a somewhat less formal medium than print, some otherwise cautious writers put aside basic rules, in my view much to their detriment. The most egregious offenses are all-caps text, all-lower-case text, and messages that use shorthand such as " $u$ " for "you" or " 2 " for "two" - they're hard to read, and annoy many people to no end. 35

Good spelling and good organization are also critical. Without the cues provided by face-to-face communication - the intelligent look in the eyes, the respectable suit - meandering or badly proofread e-mail makes the author look surprisingly bad. Some messages make their authors look like fuzzy thinkers, others like downright cranks.

Content: Some of the tips for online electronic-conference participation are well-known by now: Be careful with sarcasm and facetiousness in a medium in which the normal verbal and visual signals are absent; never post a message to hundreds of people when you're angry; when trying to respond off-list to a message, be sure it goes just to the author. Here are two less publicized pointers:

(1) When you check your e-mail after some time away from it, try to read through all the posts to a conference before responding to any one of them. Often someone else will have already said what you want to say.

(2) Readers appreciate descriptive subject lines, which help them decide what's of interest and what's not. Replies to messages automatically incorporate the original message's subject line, but if your reply veers off in a different direction, change the subject line accordingly.

\section{E. Opportunities for New Electronic Conferences}

In my view, every area of the law ought to have an electronic conference. Even if the conference doesn't produce rich debate,

35. Shorthand for common legal phrases - "1st Am" instead of "First Amendment," for example - seems more accepted. 
the other functions - research, publicity, community building remain useful. ${ }^{36}$

It's probably best to define the conference topic fairly narrowly. A conference on the law of government and religion, for instance, seems more manageable than a conference on the First Amendment or on constitutional law. You lose something by generally ruling out allied fields, but the lower traffic is likely to be more consistently interesting to all the subscribers.

In most cases, legal conferences should also be limited in membership to lawyers, with room for case-by-case exceptions. There may be categorical exceptions to this principle, especially when the legal topic is linked closely to a nonlegal field - Cyberia-L, for instance, benefits from the presence of thoughtful computer experts. Nonetheless, in my experience, legal conferences work better without laypeople.

Laypeople simply view the law in a different way than lawyers; they often make arguments that (1) lack analytic rigor; (2) seem more philosophical than legal; (3) are reasonable in the abstract but are recognized by lawyers as sure losers (for instance, because of contrary precedents); or (4) have already been studied for years by lawyers in law school. Lawyers sometimes do the same, but laypeople do it more often; though the occasional lay perspective can be a welcome breath of fresh air, a constant stream tends to be distracting.

I'm not trying to be a snob here. Most laypeople, very much including me, would be out of place at a physicists' conference, where we'd probably say things like "Light is a particle and a wave? That makes no sense!" Law can be as technical as physics, and while laypeople can sometimes add something valuable to a conference, their contributions often tend to be more distracting than useful. In a perfect world, everyone would know the rules of the conference - for instance, thoughtful and informed legal discussion only - and everyone, professional or lay, would abide by them. In reality, though, people often disregard the rules, and laypeople ignore the rules more often than professionals. Policing individual violations is complicated enough that a prophylactic bar, with exceptions made on a case-by-case basis, is probably the better bet.

36. Not all service providers are willing to set up conferences - a conference might involve a good deal of overhead for the computer system, more than is involved with an electronic newsletter or even a Web site. If a conference sends ten messages per day to 200 subscribers, the computer must process 2000 messages daily, not a crippling amount but not an insignificant one. Fortunately, a number of public-spirited institutions, especially Chicago-Kent Law School and Washburn Law School, have been good enough to set up a number of conferences on their computers, and might be open to more requests. 
Once the membership is limited, it's probably unnecessary that the conference be moderated. The list custodian should, however, keep an eye out for rudeness, for departures from the topic, and for threads that get repetitive. A few off-list messages to the transgressing participants, and an occasional on-list message, usually solve any problems.

Finally, don't be too disappointed or surprised if the conference ends up being very quiet. Some conferences never attract a critical mass of talkative and thoughtful people. I don't know why, for instance, the conference on the Religion Clauses has succeeded but the conference on the Free Speech Clause has mostly failed. Perhaps it's because Religion Clauses specialists are rarer, and they therefore feel more isolated at their schools and more in need of electronic interaction. In any case, a conference is at the mercy of its participants - if they stay quiet, nothing will happen.

\section{CONCLUSION}

The new electronic media - electronic books, electronic newsletters, and electronic conferences - can be of great help to legal professionals, both readers and would-be publishers. They can make material more accessible, timelier, cheaper, and easier to search and use. Even more important, they allow for the creation of legal resources that never could have been cost-effectively produced in print.

Today, the new media are still in their infancy. There's useful legal material out there, but often less than one would hope. Over the next few years, though, a lot more material should come around as lawyers, academics, and public interest groups find ways to profit from creating it.

Will cyberspace radically change our lives as legal professionals, or the way the legal system functions? I doubt it; any such radical change remains to be proven. LEXIS and Westlaw, for instance, influential as they have been, haven't done this.

On the other hand, LEXIS and Westlaw may be good benchmarks for us to consider. From weird and expensive technological frills, they've become the everyday tools of law professors and law students, and important in the lives of practicing lawyers, too. They've changed the way legal professionals do research, and in some significant ways they increased the sorts of research that are possible.

Cyberspace will do the same, though probably more quickly. Its exact impact on the profession is impossible to predict, but it seems to me certain that it will be significant. 


\section{Appendix: Index to Selected Cyberspace LEGAL RESOURCES}

For most list servers called listname@a.b.c, you can subscribe by sending the message "subscribe listname yourfirstname yourlastname" to listserv@a.b.c. For those marked "majordomo," you should send the message "subscribe listname" - without your name following the list name - to majordomo@a.b.c. Those marked "send message to ..." are manually operated; just send a message to the address identifying yourself, and the operator will subscribe you.

\section{Web Sites - Legal}

Lawyers' Legal Research Index http:/www.llr.com (allows full-text searches through recent case law)

The Legal List Legal Research Index

The Findlaw Index

Index of Law-Related Conferences Index of Federal \& State Case Law SEC Information FCC Information Bills in Congress, et al. Communications Law Information International Documents http://www.lcp.com/The-Legal-List/TLLhome.html (capitalization important) http://www.findlaw.com http:/www.lib.uchicago.edw/cgi-bin/law-lists http://www.law.vill.edu http://www.sec.gov http://www.fcc.gov http:/thomas.loc.gov http:/www.fcba.org http://www.law.cornell.edw/source.html

\section{Web Sites - General}

Census Information

Zip Code Information Combined White Pages

Directory of Personal E-Mail Address

Mail-Order Book Catalog

Mail-Order CD catalogs http://www.census.gov http://www.usps.gov/ncsc/lookups http://www.switchboard.com http:/www.four11.com http://www.books.com http:/www.cdnow.com http://www.cdconnection.com

\section{Electronic Newsletters - Legal}

Supreme Court Decisions

FCC Daily Digest

Law \& Politics Book Review

Law \& Economics Abstracts

Corp./Secur./Fin. Law Abstracts

Constitutional Law Abstracts

Various abstracts services provided by the

University Law Review Project

Cyberlex

\section{liibulletin@listserv.law.cornell.edu} digest@info.fcc.gov lpbr-l@piranha.acns.nwu.edu send message to sandy barnes@journal.com send message to sandy_barnes@journal.com send message to sandy_barnes@journal.com visit http://diglib.stanford.edw/lawcgi/join/ add.cgi or send an e-mail (contents irrelevant) to subscribe@thames.stanford.edu send message to cyberlaw@cyberlaw.com

\section{Electronic Newsletters - Humor and Poetry}

This is True (weekly)

Annals of Improb. Research (monthly)

Dilbert List (monthly)

Laugh of the Day (daily)

Free verse (every week or two)

Formal verse (every week or two) this-is-true@netcom.com (majordomo) mini-air@air.harvard.edu dilbertlist@internex.net lotd@world.std.com (majordomo) rpoetik@listserv.wln.com occasional-screenful@netcom.com (majordomo) 


\section{Electronic Conferences - Legal}

This is a necessarily limited list. Counsel Connect has many conferences in many areas, and there are many others on the Net proper check out http://www.lib.uchicago.edu/cgi-bin/law-lists for a more complete directory.

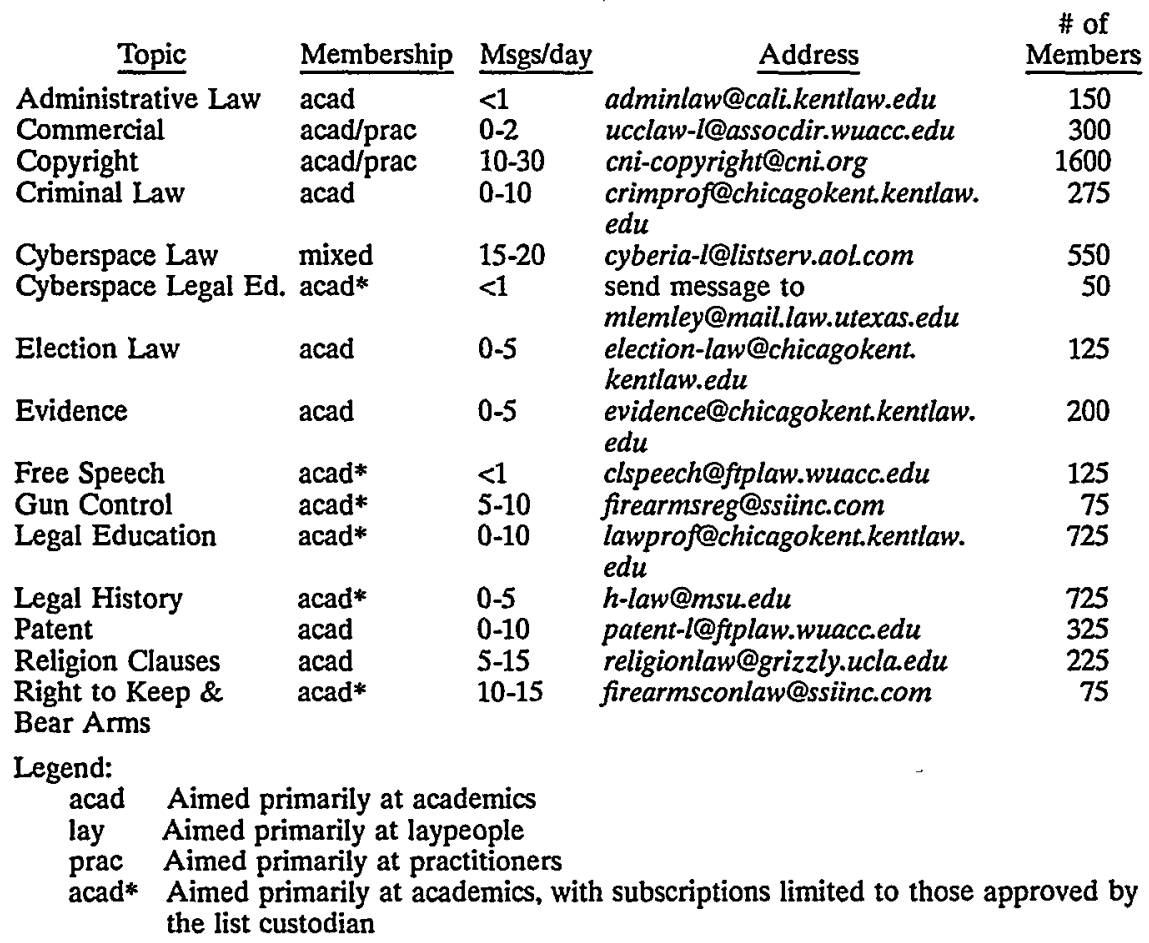


